$1-1-1970$

\title{
Optimum farm organization for a portion of the Appalachian Plateau
}

Paul E. Nesselroad

Follow this and additional works at: https://researchrepository.wvu.edu/ wv_agricultural_and_forestry_experiment_station_bulletins

\section{Digital Commons Citation}

Nesselroad, Paul E., "Optimum farm organization for a portion of the Appalachian Plateau" (1970). West Virginia Agricultural and Forestry Experiment Station Bulletins. 593T.

https://researchrepository.wvu.edu/wv_agricultural_and_forestry_experiment_station_bulletins/697 @ WVU. It has been accepted for inclusion in West Virginia Agricultural and Forestry Experiment Station Bulletins by an authorized administrator of The Research Repository @WVU. For more information, please contact ian.harmon@mail.wvu.edu. 


\section{Optimum Farm Organization For A Portion Of The Appalachian Plateau}

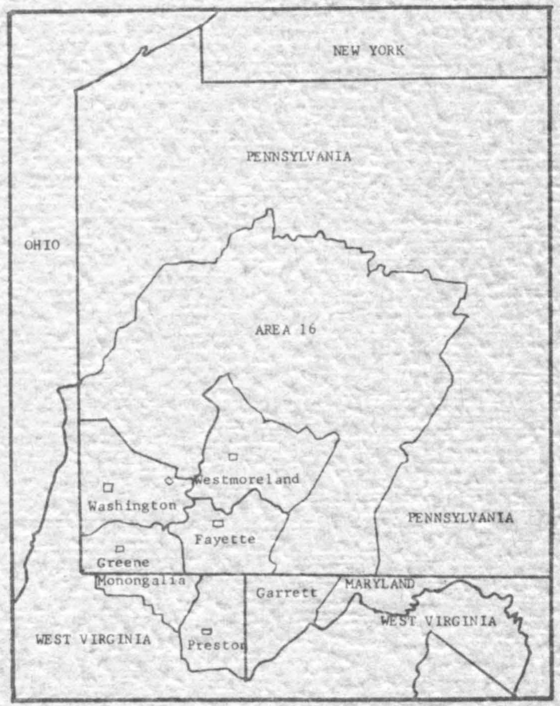

b Tocatioh of scimple segaent 


\section{CONTENTS}

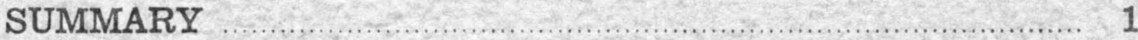

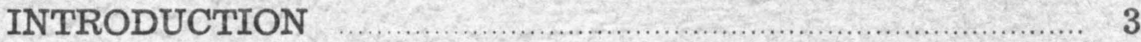

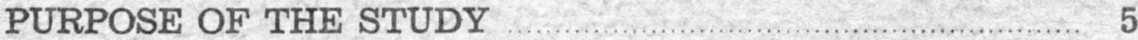

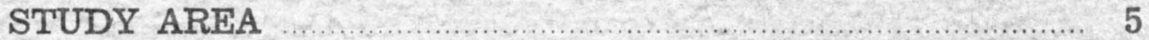

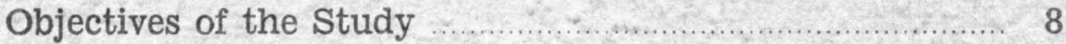

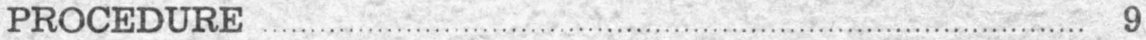

Typical Farms

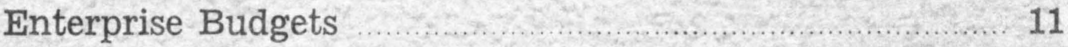

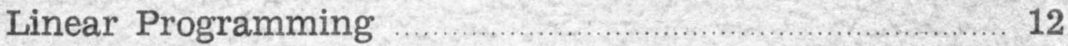

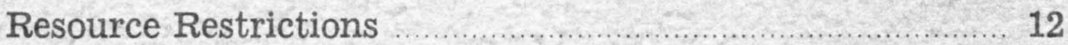

Enterprise and Resource Use Alternatives ...................... 14

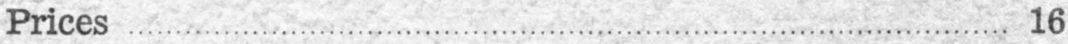

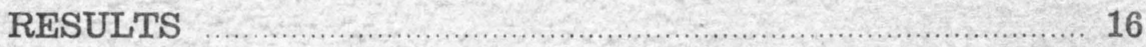

LARGE FARM

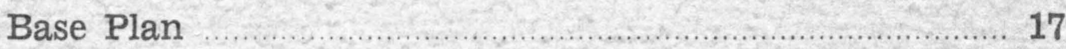

SMALL FARM

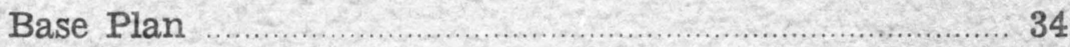

RESUME OF FARM PLANS _........... 50

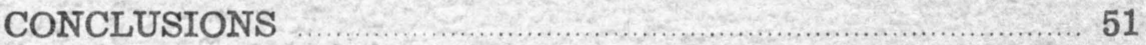

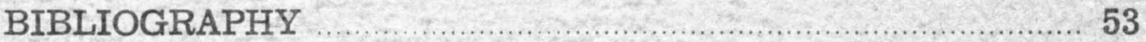

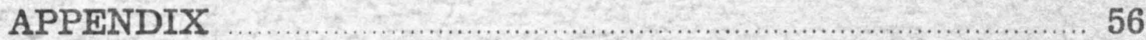




\section{SUMMARY}

Topography is a major determinant of the Land Use Capability classification in the Appalachian Region. A large proportion of the cropland is classified as Class III and IV which requires the production of forage crops and longer rotations. Dairy cows, beef cattle, and sheep are found throughout the Region to utilize the crops that are produced.

The research reported here was undertaken to determine the profit maximizing organizations of typical farms of the area.

The study area was a part of southwestern Pennsylvania, West Virginia, and Maryland. A four per cent sample of the area was taken and an inventory was made of the physical resources found and the managerial practices used on the farms.

A linear programming model of the conventional profit maximizing type was used for the analysis. The survey data were used to construct a typical large and small farm. The land acreage of the typical farms was assumed to be in proportion to the Land Class distribution of the area, and each Land Class was planned with its own alternatives and yields. In addition to land, the other restrictions included: labor, capital, buildings, and other selected resources. The quantity of investment capital that could be borrowed was the only inflexible resource.

Five dairy cow alternatives, three beef, and a sheep alternative were included in the model, as well as the commonly grown grain and hay crops.

Both the large and small farms were programmed with all alternatives open, and at a $\$ 5.00$ milk price. These solutions were termed "Base Plans." After the Base Plans were established, various changes were made in the model to reflect different situations and compared to the Base Plan. The measure of relative profitability used in all plans was net revenue.

Eight out of 11 situations for each farm reported in the study were dairy farm plans. The Base Plan for the large farm consisted of 45 dairy cows, and a net revenue of $\$ 16,460$. The Base Plan for the small farm consisted of 24 dairy cows and a net revenue of $\$ 10,019$. The net revenues of the Base Plans were the largest net revenues obtained except for $\$ 6.00$ milk. In all of the dairy plans, the highest grain-milk ratio considered was fed, except in one plan an all-forage ration was fed. Grain feeding was profitable even when it was necessary to purchase the grain.

The three dairy plans with the lowest net return were the plans with average crop yields, a $\$ 4.00$ milk price, and the all- 
forage ration. In each of the dairy plans with high crop yields, the sales of surplus grains and/or hays were important revenue sources.

To secure a farm plan not based upon dairy production, dairy cows had to be eliminated as an alternative. The first nondairy farm plan was a cash crop plan which had a return of $\$ 9,700$ for the large farm and $\$ 5,800$ for the small farm. When the sale of hay was restricted, net revenue of both farm sizes dropped below the "poverty" income level. Sheep then became the basic livestock. The large farm had a net revenue of $\$ 2,600$, while the small farm had a net revenue of $\$ 1,200$. When sheep were eliminated from consideration, a beef cattle farm plan resulted. The large farm had a net revenue of $\$ 1,900$ and the small farm had a net revenue of $\$ 800$.

The rank of profitability of the farm plans was dairy with grain feeding; dairy with an all-forage ration; a cash crop farm; a sheep, cash grain farm; and finally a beef, cash grain farm. The income level of the last two plans was entirely inadequate to justify their serious consideration.

\section{THE AUTHOR}

Paul E. Nesselroad is Assistant Agricultural Economist.

West Virginia University Agricultural Experiment Station College of Agriculture and Forestry

A. H. VanLandingham, Director Morgantown 


\section{Optimum Farm Organization For A Portion Of The Appalachian Plateau}

\section{PAUL E. NESSELROAD}

Agriculture in Appalachia ${ }^{1}$ is characterized by its smallness (Figure 1). By most measures of farm business size, Appalachian farms are smaller than those of the surrounding area ${ }^{2}$ or the United States. To illustrate the point of smallness, 133 acres was the average size per farm in Appalachia in 1964, ${ }^{3}$ compared to 151 acres per farm for the surrounding area, and 352 acres per farm for the United States. Comparable figures for land and building investment per farm in the same areas were: $\$ 17,500, \$ 34,400$, and $\$ 50,600$, respectively. The effect of small farm business size is shown by comparing the value of all farm products sold per farm for Appalachia, the surrounding area, and the United States. These respective values in 1964 were: $\$ 4,700, \$ 8,400$, and $\$ 11,200$ per farm.

Perhaps the major impediment to the development of agriculture in Appalachia is the lack of land suitable to permit the use of large-scale mechanical farm equipment. The topography of the Region is a major factor in determining the kinds of crops that are grown, the field size, and an important factor in the determination of the Land Use Capability Classification. ${ }^{4}$ The Appalachian Region is short on those Classes of land that permit an intensive type of farming, particularly grain crops. Only 30.8 per cent of the land acreage in Appalachia is classified as land Classes I-III, as compared to 55.2 per cent for the surrounding area, and 43.9 per cent for the United States. ${ }^{5}$ A much greater

${ }^{1}$ As defined here, Appalachia corresponds to the definition of the President's Appalachian Regional Commission of July, 1963 which included 323 counties in 11 states.

${ }^{2}$ Non-Appalachian counties in the Appalachian States.

${ }^{3}$ Based on data from the $\mathbf{1 9 6 4}$ United States Census of Agrieulture for the respective States and the United States.

${ }^{4}$ For an explanation of Land Use Capability classifications see, George Sharpe, Land Judging (Morgantown, W. Va.: Agricultural Extension Service, West Virginia, Circular 386), pp. 16-21.

${ }^{5}$ R. I. Coltrane and E. L. Baum, An Economie Survey of the Appalachian Region, with Special Reference to Agriculture, (Washington: United States Department of Agriculture, E. R. S., Agricultural Economics Report No. 69, 1965), Table 3, p. 69 . 
percentage of the land area is in Classes V-VIII (which can be used primarily for pasture, permanent woodland, and for recreational purposes) than in the first four land classes (which can be used primarily for row and hay crops). Likewise, the percentage of land acreage in Classes V-VIII is greater for the Appalachian Region than for the surrounding area or the United

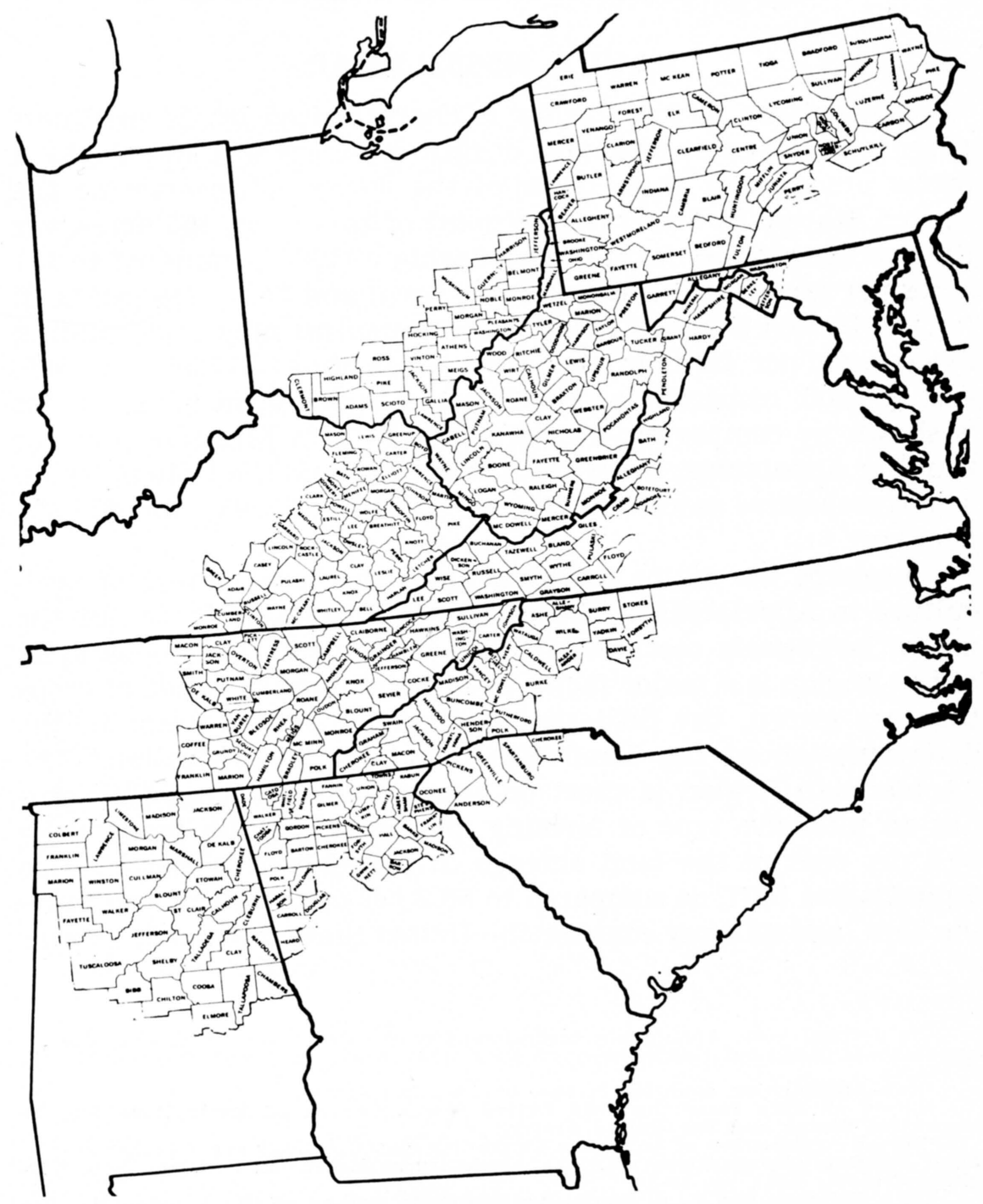
1965.

FIGURE 1. Counties Included in the Appalachian Region, 
States (55.7 per cent as compared to 29.4 per cent and 44.4 per cent, respectively) ${ }^{6}$

The adaptability of the land in the Appalachian Region to the production of forage crops for livestock feeding and the economic use of the pasture lands has led to the production of forage consuming livestock and livestock products in the Region.

\section{PURPOSE OF THE STUDY}

This study was designed to determine the most profitable of the various organizations considered, and the resulting farm plans were suitable for possible adoption on the farms of the area. No single farm organization is apt to suit the needs and desires of all farmers. Hence, the purpose of this study is to examine various modifications of organization on typical farms and to appraise the effect of these modifications on net revenue. Thus, guidelines will be provided for farmers in the area who wish to analyze their existing situations and plan improvements in their farming activities.

\section{STUDY AREA}

The area selected for study was a portion of Area 16 of the Northeast Dairy Adjustment (NEDA) study (Figure 2). Based on the 1959 Census of Agriculture, Area 16 had a total of 8,233 commercial farms. From this universe a 4.0 per cent geographically stratified, random block sample of the type used in the Master Sample of Agriculture was taken. ${ }^{8}$

Only a portion of the Area 16 sample was used in this study. This sub-sample of Area 16, hereinafter referred to as the sample, was taken from the four extreme southwestern Pennsylvania counties of Greene, Fayette, Westmoreland, and Washington; two West Virginia counties, Monongalia and Preston; and Garrett County in Maryland (Figure 3). These counties contained 3,779 commercial farms in 1959 , of which 2,363 were estimated to be dairy or potential dairy farms. ${ }^{9}$ Useable data were collected on the farm resources and farm practices from operators of 96 of these dairy or potential dairy farms.

Coltrane and Baum, loc. eit.

7The meaning of net revenue as used in this text was the difference between gross receipts and the operating costs. Costs such as depreciation, investment interest, taxes, and insurance would need to be subtracted to determine returns to non-borrowed capital, to unpaid family and operator's labor, as well as to management.

8. J. King, “The Master Sample of Agriculture," Journal of the Ameriean Statistical Association, XL (March, 1945) pp. 38-45.

${ }^{9} \mathrm{~A}$ potential dairy farm was any farm with sufficient resources to support at least 20 dairy cows. 
The study sample was selected because it contained specific desired features. They were:

1. The entire sample was in a part of a larger area defined as Appalachia (Figure 1).

2. The topography and type of soil in the sample area were such that soil conservation practices, especially forage production, were important (Table 1). Of the tillable

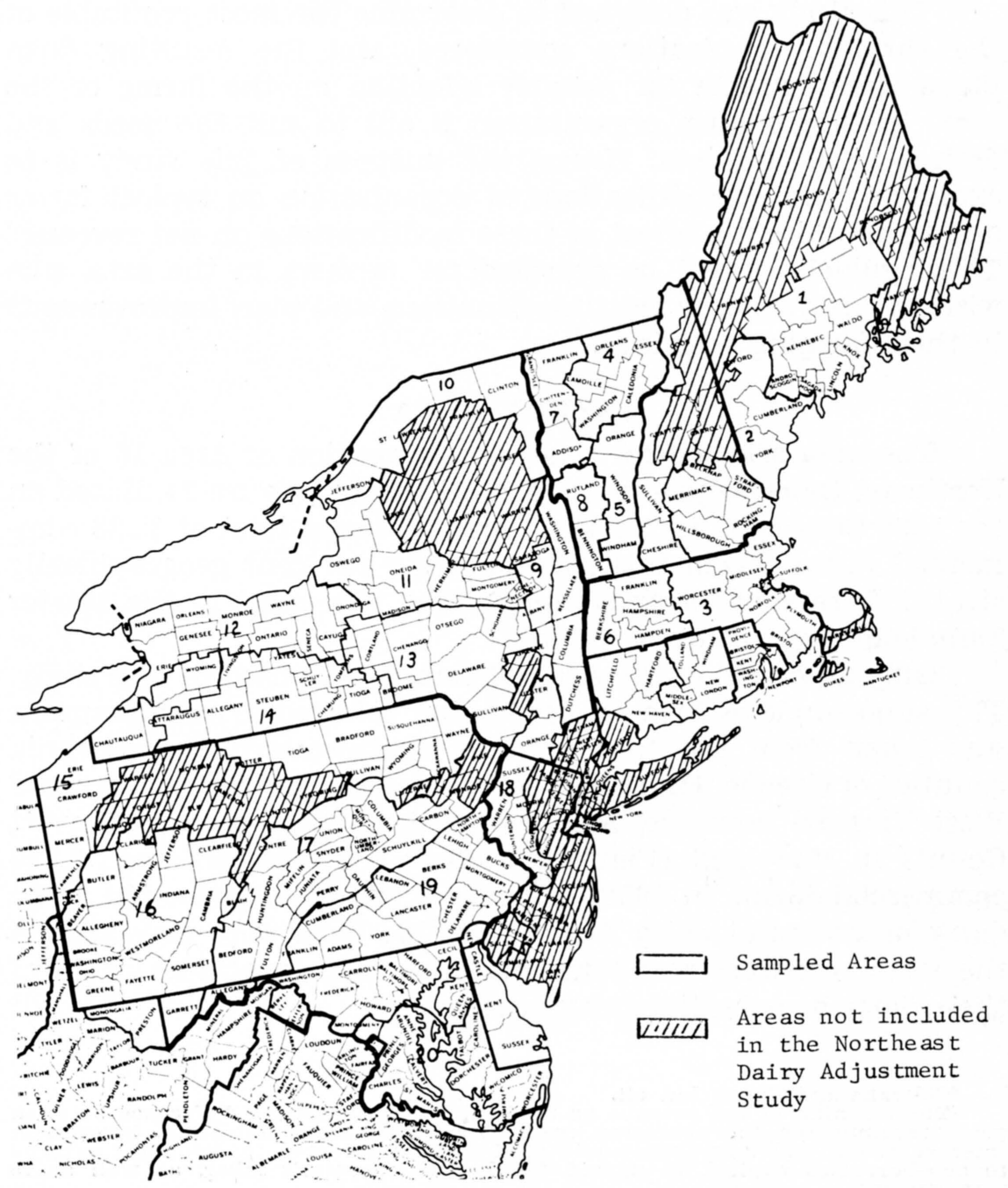

FIGURE 2. Areas of the Northeastern United States Included in the Dairy Adjustment Study. 
Land Classes, I through IV, each succeeding Class had a greater percentage of the land area requiring more stringent conservation practices than the preceding Class. Land Classes VI and VII were not tillable. Pasture

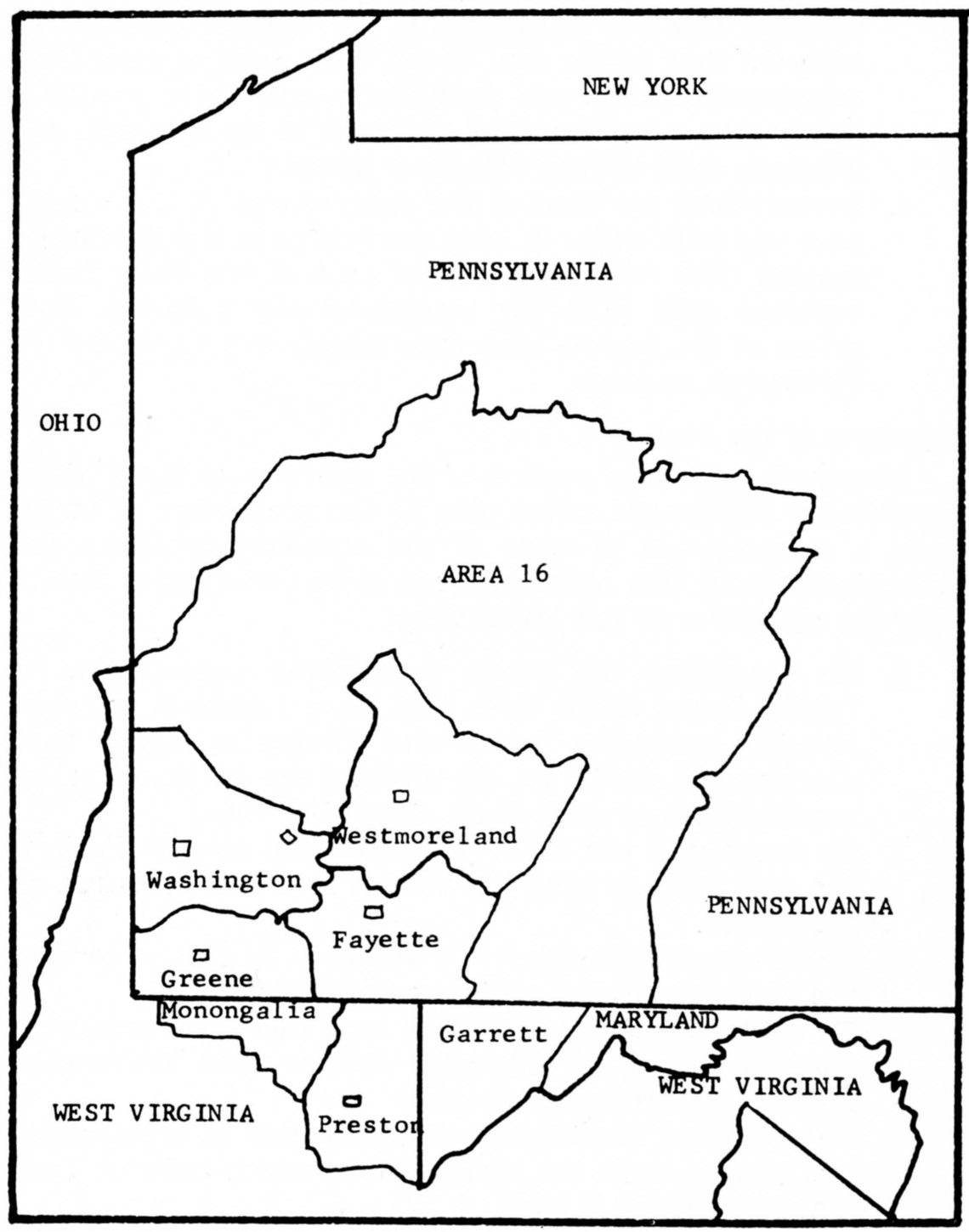

$\square$ Location of sample segment

FIGURE 3. The Study Area and Segments Included in the Survey. 
was their most intensive use. Hereinafter the small percentage of Class I land was added to the Class II land and referred to only as Class II land.

3. The major source of commercial farm income for the sampled area was dairying. The 1964 Agricultural Census reported that 48 per cent of the total value of sales from commercial farms was from dairy and dairy products. Dairy sales constituted 58 per cent of all livestock and livestock sales during the same period. ${ }^{10}$

4. Seventy-four per cent of the dairy farms of the sample area sold milk either in local markets or in the Pittsburgh market. The remaining 26 per cent of the dairy farms reported milk sales for manufacturing purposes. Milk prices of the sample area were largely influenced by the Pittsburgh market.

\section{Objectives of the Study}

Inasmuch as a large portion of the agricultural lands of the Appalachian Region are suited only to the production of forage crops, a consideration of some of the economic problems and alternatives under this restriction has been undertaken. Specifically the objectives of this study were:

1. To determine the profit maximizing organization of typical farms of the Area that have ruminant livestock and are producing grains and forages at higher than average crop yields, yet are meeting the soil conservation requirements of each Land Capability Class.

2. To investigate the effect of a reduction of crop yields to the area average upon the income level and optimum organization.

3. To investigate the effect of a variation in milk price upon the income level and optimum organization.

4. To study the effect of limited land and labor resources, and dairy cows fed all-forage rations upon the level of income and farm organization.

5. To determine the effects of adjustments in organization and income upon the typical farms which have no Land Capability Class II land.

6. To compare income levels and organization of non-dairy farms with dairy farms.

${ }^{10}$ Bureau of the Census, United States Census of Agrieulture, 1964 United States Department of Commerce, Volume 1, Part 9, Table 6, for Pennsylvania, Maryland and West Virginia. 
TABLE 1

Percentage Distribution of Acreage by Land Capability Classes of the Sampled Area

\begin{tabular}{cccccccc}
\hline \hline & I & II & III & IV & VI & VII & VIII \\
\hline Per Cent & .29 & 18.26 & 19.69 & 23.09 & 20.13 & 18.39 & .16 \\
\hline
\end{tabular}

Source: Based upon Soil and Water Conservation Needs Inventories of Maryland, Pennsylvania and West Virginia compiled by the respective State Soil Conservation Committees.

\section{Typical Farms ${ }^{11}$}

\section{PROCEDURE}

In order to accurately portray the size difference of the sampled farms, it was determined that two typical farms should be planned. The small farm represented the resources found on 43 of the sampled farms; while the large farm represented the resources of the remaining 53 farms.

Once the farms were divided into small and large farms, it was possible to construct a farm typical of each of the two size groups and determine specific resource levels for each. Data taken from the survey results were used as the basic resource quantities. However, it was necessary to adjust the farm sizes to reflect changes that were known to have occurred since the 1961 survey. The two principal changes that occurred between 1961 and 1964 were increases in acreage and in size of dairy herds. Based on a comparison of the 1959 and 1964 Censuses of Agriculture a seven per cent increase in farm size and a 16 per cent increase in dairy herd size were made and the resulting resource levels are shown in Table 2.

Quantities of labor available for farm work were standardized for man-hour equivalents and seasonal distribution as outlined by Sheehy and adopted by the NEDA study. ${ }^{12}$ The seasonal distribution of labor corresponded to the NEDA seasons of: winter - November 1 to March 15; spring-March 16 to June 30; summer-July 1 to August 31; and fall-September 1 to October 31.

${ }^{11}$ The term typical farm will be used throughout this publication and is often used in economic literature interchangeably with the term representative farm. The tvpical firm (farm) is thought to be an average firm (farm). For further discussion of the meaning see Alfred Marshall, Prineiples of Economies, 8 th ed. (London: Macmillan and Co., Ltd.) 1959, pp. 264-265.

${ }_{12}$ Seamus Sheehy, Unpublished Ph.D. Dissertation, Selection of Representative Benchmark Farms in Synthetic Supply Estimation, (University Park, Pa.: The Pennsylvania State University, Department of Agricultural Economics and Rural Sociology, 1964), p. 57-58. 
Borrowing of additional investment capital was limited to one-half the appraised value of typical farms located in the sample area less an adjustment for the existing debt. The appraised value of the typical farm was established with the assistance of the Regional Representative of the Federal Land Bank of Baltimore and his staff.

Field machinery was assumed to be that which was reported on the farms by each size group. The machinery was of adequate size to handle the cropland acreage of the existing farm plus a reasonable amount of cropland expansion. Provisions were not made for the purchase of larger machines or additional equip-

\section{TABLE 2}

Resource Levels for Typical Small and Large Farms Updated to Reflect Changes Between 1959-1964 Census of Agriculture for the Sample Area

\begin{tabular}{llrr}
\hline \hline & & \multicolumn{2}{c}{ Farm Size } \\
\cline { 3 - 4 } Resource & Unit & Small & Large \\
\hline Cropland & & & \\
Capability Class I-II & Acres & 21 & 40 \\
Capability Class III & Acres & 22 & 43 \\
Capability Class IV & Acres & 26 & 50 \\
\cline { 3 - 4 } Total Cropland & & 69 & 133 \\
Pastureland & & & \\
Capability Class VI & Acres & 23 & 43 \\
Capability Class VII & Acres & 21 & 40 \\
$\quad$ Total Pastureland & & 44 & 83 \\
Total Cropland & & & \\
and Pastureland & Acres & 113 & 216 \\
Dairy Stanchions & Head & 15 & 25 \\
Barn Space & Sq. Ft. & 1,818 & 3,000 \\
Silo Capacity & Tons & 12 & 50 \\
Available Labor by Seasons & & & \\
Winter & Hours & 1,205 & 1,532 \\
Spring & Hours & 1,152 & 1,466 \\
Summer & Hours & 702 & 893 \\
Fall & Hours & 583 & 742 \\
\cline { 2 - 4 } Total Labor & Hours & 3,642 & 4,634 \\
Available Investment Capital & $\$$ & 10,600 & 19,600 \\
\hline
\end{tabular}


ment. The small farms did not have corn pickers, field choppers, or combines. If these operations were required on the small farms they were obtained on a custom basis. Custom corn picking and grain combining increased costs about $\$ 5.00$ per acre, and field chopping about $\$ 15.00$ per acre on the small farms as compared to the large farms.

Dairy barn equipment was assumed to be that found on the sample farms. The principal barn cleaning method reported was the use of wheelbarrows. Only 1.25 per cent of the farmers reported mechanical gutter cleaners in 1961. Estimates made by extension specialists, familiar with the dairy farms of the sampled area, placed the percentage of farms with gutter cleaners at less than 25 per cent in $1967 .{ }^{13}$ Only four per cent of the dairy farms in the sample surveyed had bulk tanks. The 1964 Census of Agriculture reported 68 per cent of the dairy farms had bulk milk tanks. ${ }^{14}$ Extension specialists reported 80 per cent or greater in $1967 .{ }^{15}$ Bulk tanks were therefore assumed to be a standard piece of equipment. Pail type milking machines were reported as the predominate type (60 per cent).

\section{Enterprise Budgets}

Crop budgets were developed with the assistance of Agronomic and Soil Conservation Specialists for each of the Land Use Capability Classes of the study area. ${ }^{16}$ The budgets contained a list of all inputs needed to produce a product, cost of variable inputs (such as fertilizer and seed), man labor requirements by seasons, and the quantity of product produced (Appendix Tables 1-8). Yields used in the crop budgets were greater than the average yields for the area but were easily obtainable through the use of the budgeted cultural practices. Variable cost differences between small and large farms were recognized and were footnoted in the budgets.

Livestock budgets were also developed with the assistance of Livestock Specialists for each of the livestock enterprises considered (Appendix Tables 9-15). The variable inputs, feed requirements, and labor inputs by seasons were developed. Livestock production levels were estimated to be the same for both the small and large farms.

${ }^{13}$ Based upon estimates by Extension Specialists in Agricultural Engineering and Dairy Husbandry at West Virginia University at Morgantown, West Virginia.

${ }^{14}$ Bureau of the Census, op. eit., County Table 7.

${ }^{15}$ Extension Specialists, op. eit.

${ }_{16}$ Budgets are shown in the Appendix. 


\section{Linear Programming}

Given the quantities of available resources, the resource requirements of each crop and livestock alternative, the variable costs and the quantity of product produced by each enterprise, optimum farm organizations for the various objectives were obtained. The technique of linear programming ${ }^{17}$ was employed to determine the optimum organizations. A list of all the alternatives considered is shown in Appendix Table 16. The analysis is limited and involves the usual assumptions inherent to the linear programming procedure. The resource allocations or enterprise combinations obtained do not describe current farm organizations of the area. They are the profit maximizing organizations resulting from the allocation of the available resources among competing enterprises so as to maximize the net revenue of the farmer.

The farm organizations obtained show a greater freedom of resource allocation than may exist since the decisions are comparatively free of personal preferences, prejudices, and biases. Adoption of farm organizations such as these would depend upon farmers having better knowledge of the relative profitability of the different enterprises and a planning period sufficient for shifts of resources to be made.

\section{Resource Restrictions}

The only fixed resource in all organizations was the quantity of investment capital. The other basic resources-land, labor, and building space-of the typical farms could be increased, within limits, to accomplish some of the objectives of the study.

The soil conservation requirements for corn, small grains, and hay crops were met on each Land Class. Each of the cropland Classes had minimum and maximum rotational lengths. Hay seedings had to be made with the use of a small grain companion crop. Class II land had the most intensive rotation possibility. Corn could be grown for two sucessive years only on Class II land. Clover-timothy hay could be grown for one year or alfalfa hay for two years, making the minimum rotation three years with one year corn, small grain, and clover, or four years with two years of corn, one year each of small grain and clover. If alfalfa replaced clover then the minimum rotation length in-

${ }^{17}$ For a more thorough explanation of linear programming procedure, refer to Ralph G. Kline, Economies of Adjustments for Small Flue-Cured Tobaceo Farms, Southside Virginia. (Blacksburg. Va.: Virginia Agricultural Experiment Station, Technical Bulletin 174, June, 1964) pp. 15-19. 
creased one year. The maximum rotation on Class II land was eight years - two years of corn, one year of small grain, and five years of alfalfa.

Class III land could not be used as intensively as Class II land due to the increased slope. Corn could be grown only for one year. The minimum length rotation of corn, small grain, and hay was four years and the maximum length rotation was eight years.

Class IV land could not lay bare during the winter months, so corn grain was eliminated as a crop due to late harvest. Corn silage could be grown but early harvest was necessary in order to seed wheat in the fall for a winter cover crop. Oats was eliminated as a small grain. Hay stands were estimated to have a seven-year life. If corn silage was produced, the rotation was nine years long; without corn silage the rotation was only eight years long.

There were limits on the amount of land that could be rented, and they were in keeping with the farm machinery capacity. The rental limits were: (1) A quantity of Class II land equal to the amount of owned Class II land, and (2) one-half the acreage of the total land owned distributed by Land Capability Classes in the same proportions as the owned land. Either or both land rental amounts could be used completely or in fractional amounts.

The quantity of family labor was fixed but additional labor could be hired. There was a limit of one full-time man that could be hired. Each of the base situations was analyzed with and without a full-time laborer. Preliminary analysis found that it was profitable to have the full-time hired man on the large farm but not on the small farm. Therefore, in all analyses of the large farm, when dairy was an alternative, a full-time hired man was added to the labor supply. ${ }^{18}$ In all analyses for the small farms, and in non-dairy situations for the larger farms, family labor was the only full-time help used.

Part-time labor could also be hired. The amount considered available, however, was limited because the quality of available part-time help was considered incapable of doing all the jobs on the farm. The amount that could be hired varied according to the kinds of jobs the part-time help could perform.

Three sources of hired labor were available: (1) a full-time man; (2) year around part-time help; and (3) part-time help

${ }^{18}$ Net revenue was adjusted in those situations where a full-time hired man was added to the labor force by deducting his cost from the net returns. 
for non-school months. A full-time hired man supplied the following seasonal hours of labor: winter-1,045; spring-900; summer-380; and fall-480. An hour of part-time, non-school month help was distributed 33 per cent in the spring season and 67 per cent in the summer season.

\section{Enterprise and Resource Use Alternatives}

Crop yield estimates were adjusted by Land Capability Classes to reflect the effects of erosion and the lack of moisture retention. For instance, corn silage yields were decreased by 20 per cent from Class II land to Class III land, and by 40 per cent from Class II land to Class IV land. The appropriate yield decrease was estimated for each crop. Labor coefficients were increased as the Land Capability Class increased to reflect the loss of machine efficiency on the steeper slopes.

Limited data were available on the rate of loss of machinery efficiency as slope increased. Based on a review of the literature and a survey of specialists, overall loss of machinery efficiency was estimated at a 10 per cent differential between Land Class II and Land Class III and a 25 per cent differential between Class II and Class IV. Since manpower was required for machinery operation the manpower for performing jobs between the various Land Classes increased by the same percentage as did machine time.

In summary, two factors reflected crop differences as they were grown on the different Land Capability Classes. The first was reduced crop yields from the same quantity of inputs. The second was higher production costs created by increased machinery costs from decreased machinery efficiency and increased manpower requirements.

The commonly grown crops were considered as alternatives; two hay crops - clover-timothy mixtures and alfalfa; and three grain crops-corn, wheat, and oats. The T.D.N. values of all grain crops were converted to corn equivalents. All grains could be grown, fed, sold, or purchased. Hay could be sold or purchased. If crops were sold rather than marketed through livestock, it was assumed that the quantities harvested were also the quantities sold. If crops were fed to livestock the quantity of T.D.N. was reduced to reflect storage and feeding losses. Corn grain or oats could not be grown on Class IV land.

Clover-timothy hay mixtures were harvested only as hay. The first year of clover hay was satisfactory for dairy purposes, 
but after the first year it was satisfactory only for other ruminant livestock. The length of the clover-timothy stand varied from one to four years depending upon the Land Capability Class. Alfalfa was harvested with the first of three cuttings for silage or hay, and the remaining cuttings for hay purposes only. All alfalfa was satisfactory for either dairy or non-dairy enterprises. Alfalfa stand lengths varied from two to seven years depending upon Land Capability Class.

Only the forage consuming classes of livestock commonly found in the sample area were considered as alternatives. The 1,200-pound dairy cow was assumed to be capable of consuming annually 11,000 pounds of dry matter from medium or better quality of roughage. ${ }^{19}$ By varying the grain to forage ratio, the milk production could be increased with additional inputs of grain. Five levels of milk production were considered: 9,000; 10,$000 ; 11,000 ; 12,000$; and 13,000 pounds of milk. The five dairy rations included in the model met the T.D.N. requirements for maintenance, production, and reproduction, as well as the requirements of digestible protein within the 11,000-pound maximum of dry matter. Three types of beef production were examined: beef cow-calf to 450 pounds; spring feeder calf from 450 to 600 pounds; and yearling grass fat beef from 600 to 818 pounds. A ewe-lamb enterprise was considered with 128 pounds of lamb being sold per ewe.

Pasture alternative; were of two types, improved and unimproved. All Land Class III pasture was assumed to be improved pasture. Pastures on Land Classes IV, VI, and VII were either unimproved or improved at appropriate costs and yields. All pastures were rotationally grazed. No provision was made for the harvest of surplus pasture during the months of May and June. Provision was made for the feeding of silage to supplement the pasture deficiencies of July, August, and September. Sudangrass could also be grown and used as a summer pasture supplement.

All operating capital was borrowed at an eight per cent interest charge and was used for all purposes other than the costs of building or livestock expansion. Investment capital was used for the latter two purposes. Additional buildings, silos, and livestock could only be expanded to the limits of the available investment capital. Interest was charged at six per cent on the

\footnotetext{
${ }^{19}$ Based on Edward J. Smith, Profitable Use of High-Quality Forage on a Wisconsin Dairy Farm, (Madison, Wisconsin: Department of Agricultural Economics, Ag. Econ. 18, July, 1956) pp. 5-6 and 35-39.
} 
investment capital. The interest charges also served as reservation prices for the use of capital.

Two off-farm job alternatives were available. One was hourly winter work off the farm at $\$ 1.00$ per hour for either the operator or his full-time hired man. The other was a part-time job; the example used was school bus driving. Driving a school bus required 360 hours of winter labor, 204 hours of spring labor, 164 hours of fall labor, and provided a $\$ 1,200$ net income.

Other activities considered in the analysis were the renting out of all land, bedding purchases, and a block of fixed labor for care of the dairy herd if the optimum plan was based upon dairy livestock.

\section{Prices}

Price levels chosen for the inputs and outputs generally were the same as those reported in the A.E. \& R.S. Bulletin 51, Agricultural Planning Data for the Northeastern United States, ${ }^{20}$ especially for machinery costs, prices paid, prices received, and fixed costs. These prices were developed from U.S. Department of Agriculture data for the years of 1959-61. Adjustments were made on some items to reflect recent trends and were based upon Crop and Livestock Annual Summaries for 1967, and the monthly Price Report releases. Milk prices for the sample area for 1966 and 1967 were supplied by the Dairymen's Cooperative Sales Association. The average blend prices for milk per hundredweight with adjustments for butterfat test and less hauling costs for the Pittsburgh markets were $\$ 4.80$ in 1966 and $\$ 5.22$ in 1967.

\section{RESULTS}

Optimum farm plans were determined for both the large and small farms with all the alternatives considered, with maximum resource expansion possibilities and with the price of milk at $\$ 5.00$ per hundredweight. These solutions were considered the "Base Plan" for each farm size. After the Base Plan had been established input-output coefficients were altered to reflect reduced crop yields; some of the alternatives were eliminated from consideration; milk prices were changed; or the resource levels were altered to analyze other situations typical of conditions found in the area.

${ }^{20}$ Agrieultural Planning Data for the Northeastern United States, (University Park, Pa.: Department of Agricultural Economics and Rural Sociology, A. E. \& R. S. 51, July, 1965). 
The hypothetical effect of the different alternatives upon the farm organization and income levels were compared with the Base Plans. Essentially these Base situations represented the most profitable organization that farmers of the area could achieve among all of the alternatives examined and with the resources specified as available to them. Changes in profitability and farm organization due to eliminating certain alternatives and resources were then compared with the Base situation. Such changes were analyzed in order to reflect situations that do exist among farms in the area.

\section{Base Plan}

\section{LARGE FARM}

The Base Plan for the large farm essentially was a 45-cow dairy herd fed the maximum amount of grain permitted (one pound of grain for each 4.75 pounds of milk). In addition to the milk sold at the Base price of $\$ 5.00$ per hundredweight, 263 tons of hay were sold and 421 hours were worked off-farm during the winter to produce the net revenue of $\$ 16,460$ (Table 3). Other potential sources of income such as beef, sheep, and sales of grain did not become a part of the Base Plan.

The original dairy barn space for 25 cows was first increased by remodeling to add three cows and then expanded to accomodate 17 more cows. Additional space was added to care for 14 head of raised replacements. Silo capacity was also expanded by 156 tons. These expansions plus the additional investment in cows completely exhausted the available investment credit.

In this plan the business was expanded by renting 40 acres of Class II and 108 acres of land with a Land Class distribution equivalent to the original land base. This was the maximum amount of land that the existing field machinery complement was capable of handling. However, additional cropland would have added substantially to the net return.

The rotations planned for each Land Class were of the long or extensive type rather than the short or intensive type. The most intensive land use was two-year corn on Class II land. The most extensive land use was seven years of hay on Class IV. For each seven acres of hay on Class IV land, one acre of corn could be produced. However, the land could not lay bare during the winter months. The cover crop requirements of Class IV land meant that corn silage could be grown but not corn grain. In order to meet the corn silage requirements of the dairy herd in 
the Base Plan, it was necessary to produce one acre of corn silage on the Class IV land. The resulting crop rotation on Class IV land was one acre of corn silage, one acre of wheat, and seven acres of hay.

Livestock pasture needs were met by the 66 acres of Class IV unimproved pasture and 65 acres of Class VI pasture plus supplementary feeding of corn silage. A total of 36,000 pounds of pasture T.D.N. was unused during the May-June pasture season, and 38,000 pounds of corn silage T.D.N. were fed during the pasture shortage of late summer. Since 263 tons of hay were sold, the pasture shortage and forage requirements for the additional cows could have been satisfied by feeding hay rather than silage, thus avoiding the cost of silo expansion. This alternative was not considered in the analysis.

The operator, his family, and one full-time hired man provided the needed labor. All of their available time was utilized in the spring and fall. Excess winter labor was employed off the farm. In reality the 400 hours probably would not be worked offfarm during the winter. If this were true, the net revenue would decrease by $\$ 400$.

Several factors which limited further expansion and income were: (1) All available investment capital was used. An additional hundred dollars of investment capital would have increased net revenue by a little over nine dollars more than the interest charge. If such additional capital had been available, more land could have been rented, but in this case a new complement of field equipment would have been necessary to handle the expanded acreage. Also if more investment capital had been available the dairy could have been expanded. An expanded dairy, however, would also have required additional labor. (2) The available labor in the spring and fall was entirely used. Such labor shortages, however, might well have been profitably overcome by hiring additional help.

\section{Differences in Income and Farm Organization with Average}

\section{Crop Yields}

The assumption was made in this study that a farmer who wanted to reorganize his business for maximum profit would adopt and follow recommended practices to achieve greater than average crop yields. To demonstrate the profitability of following such recommendations, the optimum farm organization, resource use, and returns were determined using average crop yields. 
TABLE 3

Optimum Farm Plans, Large Farms, All Alternatives

Considered, $\$ 5.00$ Milk

\begin{tabular}{|c|c|c|c|}
\hline \multirow[b]{2}{*}{ Item } & \multirow[b]{2}{*}{ Unit } & \multicolumn{2}{|c|}{ Level of Crop Yields } \\
\hline & & $\begin{array}{c}\text { High } \\
\text { (Base) }\end{array}$ & Average \\
\hline
\end{tabular}

Livestock:

Dairy cows (1 lb.

grain/4.75 lbs. milk)

Head

45

30

Dairy replacement, raised

Head

14

10

Land:

Owned

Whole farm rented in

Class II only rented in

Class II rented out

Acres

216

216

Acres

108

Acres

Acres

108

40

$\overline{14}$

Crops:

Class II land

Corn, 2 yr.

Corn silage, 2 yr.

Oats

Wheat

Alfalfa hay, 5 yr.

Class III land

Corn, 1 yr.

Oats

Alfalfa hay, 6 yr.

Class IV land

Corn silage, 1 yr.

Wheat

Alfalfa hay, $7 \mathrm{yr}$.

Unimproved pasture

Class VI unimproved

pasture

Class VII idle

Crop purchases or sales:

Labor:

Hay sales

Hay purchases

Total available labor

Operator and family

Full-time hired

Part-time,

year around hired

Work off-farm-winter

Labor unused-summer

Capital:

Investment capital limit

Investment capital unused

Operating capital used

Net revenue
Acres

Acres

Acres

Acres

Acres

Acres

Acres

Acres

Acres

Acres

Acres

Acres

Acres

Acres

Tons

Tons

Hours

Hours

Hours

Hours

Hours

Hours

$\$$
11

14

12

$\overline{63}$

8

8

48

11

12

5

7

11

8

8

48

$\begin{aligned} 1 & - \\ 7 & - \\ 66 & \overline{75}\end{aligned}$

65

60

65

60

263

17

4,634

7,539

4,634

2,905

4,634

10

$\overline{421}$

26

$\begin{array}{lrr}\$ & 29,600 & 29,600 \\ \$ & - & 15,570 \\ \$ & 15,682 & 8,374 \\ \$ & 16,460 & 12,100\end{array}$


With average crop yields, net returns were only $\$ 12,000$ as compared with $\$ 16,460$ at greater than average yields (Table 3 ).

Changes in the farm organization included a reduction from 45 to 30 cows and the farm was operated entirely with family help. No hay was produced for sale and winter labor requirements were such that off-farm work was impossible.

In this plan it was not profitable to rent any Class II land alone. In fact, 14 acres of Class II land were rented out. The principal changes in land use were a shift from alfalfa to clovertimothy on Class II land, and the use of all Class IV land for unimproved pasture.

With average yields over 50 per cent of the available investment capital was unused.

Differences in Income and Farm Organization with $\$ 4.00$ Milk Price

The farm price for milk in the Pittsburgh Market has been gradually increasing during the past three years, and has averaged about $\$ 5.00$ per hundredweight. Some farmers of the area have responded to the gradual price increases by increasing their dairy herd size. On the other hand, there is always a possibility that prices may decrease. The variation from the Base situation was used to observe the organizational adjustments that would occur if the price of milk decreased to $\$ 4.00$.

A dollar decrease in the milk price caused a contraction in the dairy herd size from 45 to 31 dairy cows (Table 4 ). The decline in number of dairy cows and the dollar decrease in milk price caused a $\$ 5,573$ drop in net revenue from $\$ 16,460$ to $\$ 10,887$. The reduction in the milk price did not affect the level of grain feeding. In fact, a reduction in grain feeding to the next level would have reduced income by $\$ 22.68$ per cow. Continued reductions in the grain-milk ratio would result in even greater income losses. Likewise, a change to beef or sheep would have resulted in even larger income reductions.

The same acreage of land was farmed with $\$ 4.00$ milk as in the Base Plan. About the same crop rotation was also followed on Land Class II and III as in the Base Plan. The principal difference in land use was on Class IV land where only the saleable crops of wheat and hay were grown. The decreased cow numbers released labor that had no profitable use except the production of saleable crops. Sufficient pasture was available for the livestock without the use of Class IV as pastureland. Therefore, the 
TABLE 4

Optimum Farm Plans, Large Farms, All Alternatives Considered with $\$ 4.00$ and $\$ 6.00$ Milk Compared to the $\$ 5.00$ Milk Base Plan

\section{Item}

Plans with Milk Prices Of:

\begin{tabular}{|c|c|}
\hline$\$ 4.00$ & $\begin{array}{c}\$ 5.00 \\
\text { (Base) }\end{array}$ \\
\hline
\end{tabular}

Livestock:

Dairy cow (1 lb.

grain $/ 4.75$ lbs. milk) Head

Dairy replacements, raised Head Land:

Owned

Whole farm rented in

Class II only rented in

Unit

Acres

Acres

Acres

31

45

46

$10 \quad 14$

15

$216 \quad 216 \quad 216$

108

40

108

40

108

40

Crops:

Class II land

Corn, 2 yr.

Corn silage, 2 yr.

Oats

Wheat

Alfalfa hay, 5 yr.

Class III land

Corn, 1 yr.

Oats

Alfalfa hay, $6 \mathrm{yr}$.

Class IV land

Corn silage, $1 \mathrm{yr}$.

Wheat

Alfalfa hay, $7 \mathrm{yr}$.

Improved pasture

Unimproved pasture

Class VI unimproved

pasture

Class VII idle

Crop sales:

Corn equivalent sales Hay sales

Labor:

Total available labor

Operator and family

Full-time hired

Work off-farm-winter

Labor unused

Spring

Summer

Acres

13

12

11

14

12

Acres

12

Acres

Acres

$\overline{63}$

63

3

10

Acres

Acres

Acres

8

8

48

8

62

Acres

Acres

Acres

Acres

Acres

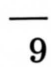

66

Acres

Acres

65

60

8
48

8

8

48

Bushels $\quad 910$

Tons

442

263

243

Hours

7,539

7,539

7,539

Hours

4,634

4.634

4634

Hours

2,905

Hours

1,011

2.905

421

383

Hours

120

Hours

51

$\overline{26}$

$\overline{24}$

Capital:

Investment capital limit

Investment capital unused \$ Operating capital used Net revenue:

$\begin{array}{llrr}\$ & 29,600 & 29,600 & 29,600 \\ \$ & 13,669 & - & - \\ \$ & 16,408 & 15,682 & 15,717 \\ \$ & 10,887 & 16,460 & 22,385\end{array}$


Class IV land was cropped for cash sale to employ profitably the available labor.

Less grain and hay were required for feed with fewer cows. Hay sales increased to 442 tons; and in addition 910 bushels of corn equivalent were sold.

Even after cropping the Class IV land, some spring and summer labor was unused and a total of 1,011 hours was worked off the farm during the winter. The critical labor period was the fall season when all of the available labor was employed.

In spite of adding an additional 100 tons of silo capacity and building space for six cows, $\$ 13,669$ of investment capital was unused.

\section{Differences in Income and Farm Organization with $\$ 6.00$} Milk Price

If milk prices continue to increase during the next few years, it is expected that further organizational changes will be made. The milk price was increased from $\$ 5.00$ to $\$ 6.00$ in order to observe the nature and extent of the organizational changes, and what resource adjustments would be needed to maximize the net revenue from an increasing market price.

Compared to the Base Plan only minor changes occurred in the physical organization of the farm with the $\$ 6.00$ milk price (Table 4). Net returns increased from $\$ 16,460$ to $\$ 22,385$ but 98 per cent of the increased revenue could be attributed to just the increase in milk price. The reason no major changes took place in the physical organization of the farm was the shortage of investment capital as well as of spring and fall labor. All of the available investment capital had been utilized in the Base Plan so there was little chance for additional dairy expansion at the $\$ 6.00$ milk price. However, there was no physical restriction on the quantity of operating capital that could be borrowed. Thus, through the utilization of some additional operating capital to improve 30 acres of Class IV pastureland enough investment capital was saved through the elimination of some silo expansion to add one more dairy cow. Another hundred dollars of investment capital would have added $\$ 15.66$ to the net revenue above its cost.

As with the $\$ 4.00$ - and $\$ 5.00$-milk-price plans, all of the land was rented that was permitted under the assumptions of this study. The production of crops was confined to Land Classes II and III. Fewer acres of corn silage and hay were produced and 
more acres of feed grains were grown. All of the feed grains needed were produced on the farm. Hay was still sold as a cash crop but the quantity was 20 tons less than in the Base Plan.

The reduction in corn silage and hay acreage released some fall labor but fall labor still remained a critical resource. Part of the released fall labor was used to care for the additional cow, and the remaining fall labor was used to seed the fall wheat on the Class II land. It was necessary to gain spring labor, as well as fall labor, to care for the additional cow as all the spring labor had been utilized in the Base Plan. The switch from oats to wheat released some of the needed spring labor. The total quantities of both spring and fall labor were again used.

In the Base Plan, as well as in the $\$ 4.00$ and $\$ 6.00$ milk price plans, the use of the Class IV land shifted with available labor supply. When spring, summer, and fall labor was readily available, the land was farmed as a means of obtaining a return on unused labor. When the supplies of cropping season labor were utilized at more profitable tasks, the Class IV land was mostly pastured. When the cropping season labor became very short, all the Class IV land was pastured. The remainder of the cropland, Class II and III, had essentially the same cropping pattern with $\$ 4.00$, $\$ 5.00$, and $\$ 6.00$ milk prices.

Differences in Income and Farm Organization when Restricted to No Resource Expansion and No Work Off-Farm

Some farmers either cannot or will not consider an expansion program. A shortage of available land and labor, either real or imaginary, might be an explanation why some farmers do not expand their operations. Other operators may have reached an age that they do not want to make organizational changes. A comparison of the net revenue and associated organization of the Base Plan with the farm without resource expansion could provide the motivation for some farmers to reappraise their expansion possibilities.

At equal milk prices the restrictions of no resource expansion and no work off-farm reduced net revenue to $\$ 14,171$, down $\$ 2,289$ from that of the Base Plan (Table 5). The decrease in net revenue was the result of a reduction of dairy cow numbers from 45 to 30 cows and hay sales from 263 tons to 45 tons.

The 30 dairy cows in this plan represented an expansion of five over the original barn capacity. Silo capacity was also expanded by 58 tons, but in spite of these expansions, $\$ 14,523$ of 
investment capital went unused. There were still no beef or sheep in the plan.

An intensification of the rotation on Land Class II occurred. One-year clover hay was produced rather than five-year alfalfa. The shortened hay stand permitted a relatively greater proportion of the land for corn production. The crop rotation on Land Class III was the same as the Base Plan except fewer acres of land were available. All of Land Class IV was used for pasture.

The family labor was almost completely utilized in all seasons. The only unused labor was 64 hours of summer labor. A shortage of labor existed in the spring and fall, with fall labor being more restrictive than spring labor.

Differences in Income and Farm Organization when Restricted to No Resource Expansion, No Work Off-Farm and All-Forage Fed Cows

It has been shown that a variation of the product price did not affect the most profitable grain-milk ratio. Also an increase in the grain cost through reduced crop yields did not affect this ratio. Using the same production function, it was possible to gain some insight of the effect of eliminating grain feeding entirely. The milk output per cow would be reduced from 13,000 pounds to 9,400 pounds. Comparisons were then made between grain and no grain feeding of dairy cattle, and the other all-forage livestock classes such as beef and sheep.

Net revenue dropped from the Base Plan level of $\$ 16,460$ to $\$ 11,015$ (Table 5). Compared to the Base Plan, 14 fewer dairy cows were kept. Even with the sharp drop in the level of milk production, however, the dairy enterprise was much more profitable than beef or sheep.

In order to house the 31 dairy cows, the existing dairy barn capacity was increased by six cows. Silo capacity was also increased by 112 tons. Some of the additional silo capacity was necessary for the storage of ensilage used as summer feed. In spite of the expansion of physical facilities, $\$ 13,029$ of investment capital was unused.

Only Class II and III lands were used for crop production. As would be expected, emphasis was placed upon the production of corn silage and hay crops. Some small grains were produced as required by the rotation and conservation needs, and three acres of corn grain were grown. The small grains and corn as well as 79 tons of surplus hay were sold as cash crops. The Class IV 


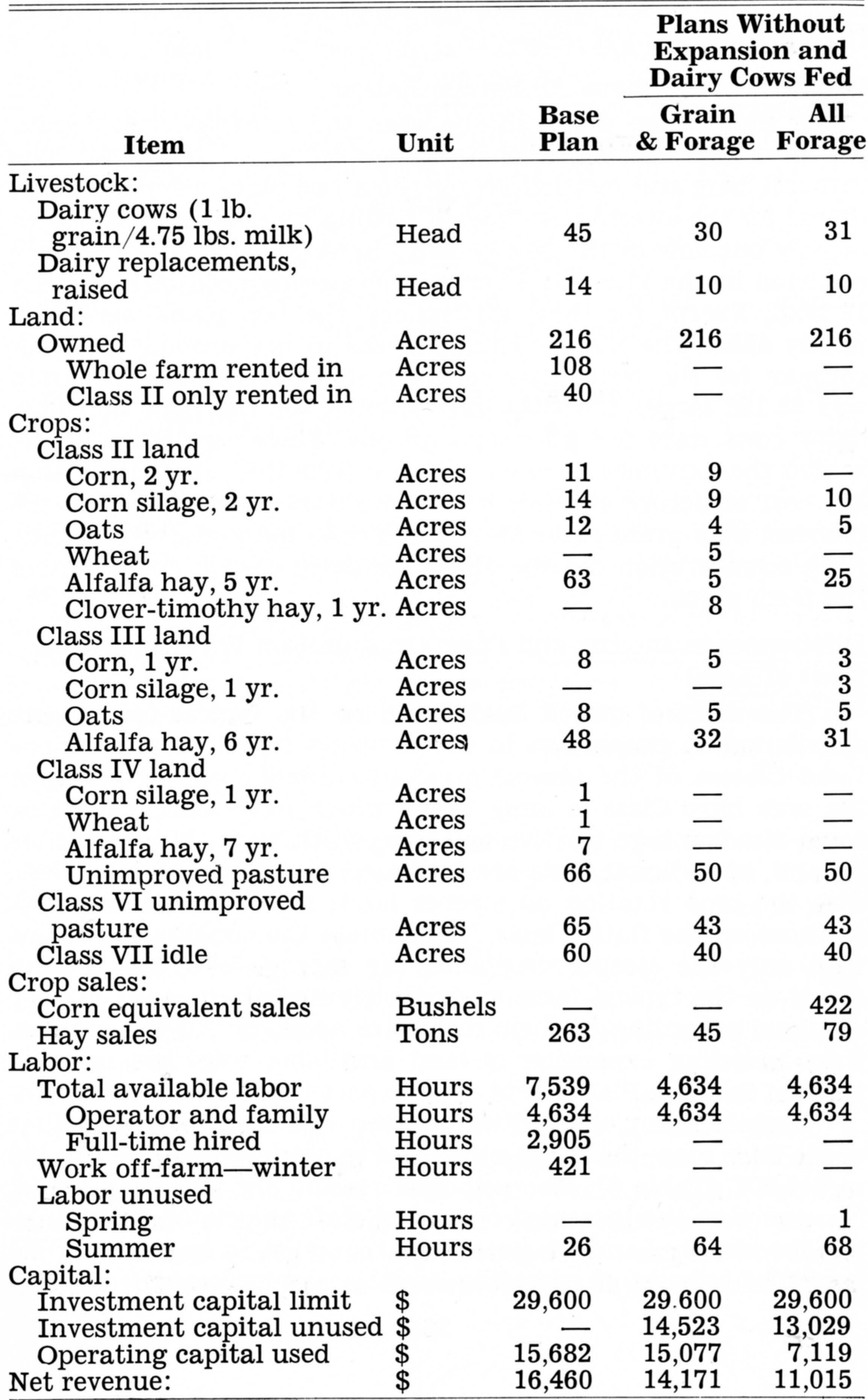


and VI lands were used entirely as unimproved pasture. The summer pasture deficit was met by supplementary feeding rather than using Class VII land.

\section{Grain Rations Versus All-Forage Ration}

A comparison was made between the farm plan with grain fed cows and the one with all-forage fed cows (Table 5). The resource base and restrictions for these two plans were the same, except for the alternative of grain feeding. There was a difference of only one cow in the size of dairy herd. Some small difference occurred in the kinds and acres of crops produced on the Class II land. Except for these differences, the two plans were very nearly alike. The major difference was in net revenue. The net revenue for the farm plan in which dairy cows were fed grain was \$3,156 larger than the net revenue for the plan in which dairy cows were fed all-forage rations. These two plans represented the extremes of dairy ration alternatives studied. Within the cost structure studied, it was profitable to always feed the heaviest milk-grain ratio. Only when cows fed grain were barred from consideration did the all-forage dairy cows become part of the farm plans.

\section{Differences in Income and Farm Organization With No Owned}

\section{Class II Land}

The acres of owned land found on the typical farms were distributed in proportion to the acreages found in the various Land Classes of the sample area. In actuality not all farms of the area have Class II land. Those which have none operate at some disadvantage relative to those which have. Without Class II land, operational costs are increased and crop yields are less. Also the crop rotation on steeper lands cannot be as intensive as those on the flatter land. To simulate the condition of farms with only the steeper croplands the acreage of Class II land found on the typical farm was redistributed as Class III and IV cropland according to their respective acreages. All the alternatives including expansion of land and labor were the same as those of the Base Plan except that no part-time job was permitted.

Despite many similarities between this farm plan and that of the Base Plan, there was a decrease in net revenue from $\$ 16,460$ to $\$ 15,007$ (Table 6). The principal reasons for this drop in net revenue were the increased operating costs associated with farming the steeper Land Classes and a reduction in hay sales by 23 tons. The amount of operating capital used increased from $\$ 15$,- 
TABLE 6

Optimum Farm Plans, Large Farms, \$5.00 Milk, All Alternatives Considered Except No Owned Class II Land, and No Part-Time Job Compared to the Base Plan

\begin{tabular}{|c|c|c|c|c|}
\hline & \multirow[b]{2}{*}{ Unit } & \multirow[b]{2}{*}{$\begin{array}{l}\text { Base } \\
\text { Plan }\end{array}$} & \multicolumn{2}{|c|}{$\begin{array}{l}\text { Plans With } \\
\text { Corn Grain }\end{array}$} \\
\hline Item & & & Raised & $\begin{array}{l}\text { Pur- } \\
\text { chased }\end{array}$ \\
\hline \multicolumn{5}{|l|}{ Livestock: } \\
\hline $\begin{array}{l}\text { Dairy cows ( } 1 \text { lb. } \\
\text { grain } / 4.75 \text { lbs. milk) }\end{array}$ & Head & 45 & 45 & 45 \\
\hline $\begin{array}{l}\text { Dairy replacements, } \\
\text { raised }\end{array}$ & Head & 14 & 14 & 14 \\
\hline Land: & Acres & 216 & 216 & 216 \\
\hline $\begin{array}{l}\text { Owned } \\
\text { Whole farm rented in }\end{array}$ & Acres & 108 & 108 & $\begin{array}{l}216 \\
108\end{array}$ \\
\hline Class II only rented in & Acres & 40 & 40 & 40 \\
\hline \multicolumn{5}{|l|}{$\begin{array}{l}\text { Crops: } \\
\text { Class II land }\end{array}$} \\
\hline $\begin{array}{l}\text { Class II land } \\
\text { Corn, } 2 \text { vr. }\end{array}$ & Acres & 11 & 4 & - \\
\hline $\begin{array}{l}\text { Corn, } 2 \text { yr. } \\
\text { Corn silage, } 1 \text { yr. }\end{array}$ & Acres & - & - & $\overline{2}$ \\
\hline Corn silage, 2 yr. & Acres & 14 & 11 & 12 \\
\hline Oats & Acres & 12 & 8 & - \\
\hline Wheat & Acres & - & $\overline{0}$ & 8 \\
\hline Alfalfa hay, 5 yr. & Acres & 63 & 37 & 38 \\
\hline \multicolumn{5}{|l|}{ Class III land } \\
\hline $\begin{array}{l}\text { Corn, } 1 \text { yr. } \\
\text { Oats }\end{array}$ & Acres & 8 & 10 & - \\
\hline $\begin{array}{l}\text { Oats } \\
\text { Wheat }\end{array}$ & Acres & 8 & 10 & $\overline{19}$ \\
\hline $\begin{array}{l}\text { Wheat } \\
\text { Alfalfa hay, } 6 \text { yr. }\end{array}$ & $\begin{array}{l}\text { Acres } \\
\text { Acres }\end{array}$ & $\overline{48}$ & $\overline{59}$ & $\begin{array}{l}12 \\
71\end{array}$ \\
\hline $\begin{array}{l}\text { Alfalfa hay, } 6 \text { yr. } \\
\text { Sudan pasture }\end{array}$ & $\begin{array}{l}\text { Acres } \\
\text { Acres }\end{array}$ & - & 4 & - \\
\hline \multicolumn{5}{|l|}{ Class IV land } \\
\hline Corn silage, 1 yr. & Acres & 1 & 4 & - \\
\hline Wheat & Acres & 1 & 4 & 1 \\
\hline Alfalfa hay, 7 yr. & Acres & 7 & 23 & 9 \\
\hline Improved pasture & Acres & - & 4 & $\overline{0}$ \\
\hline Unimproved pasture & Acres & 66 & 65 & 86 \\
\hline $\begin{array}{l}\text { Class VI unimproved } \\
\text { pasture }\end{array}$ & Acres & 65 & 65 & 65 \\
\hline Class VII idle & Acres & 60 & 60 & 60 \\
\hline \multicolumn{5}{|c|}{ Crop purchases or sales: } \\
\hline Corn equivalent purchases & Bushels & - & 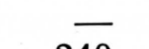 & 1,928 \\
\hline Hay sales & Tons & 263 & 240 & 244 \\
\hline \multicolumn{5}{|l|}{ Labor: } \\
\hline Total available labor & Hours & 7,539 & 7.539 & $\begin{array}{l}7,539 \\
4634\end{array}$ \\
\hline Operator and family & Hours & 4,634 & $\begin{array}{l}4.634 \\
2905\end{array}$ & $\begin{array}{l}4,634 \\
2905\end{array}$ \\
\hline Full-time hired & Hours & 2,905 & $\begin{array}{r}2,905 \\
411\end{array}$ & $\begin{array}{r}2,905 \\
408\end{array}$ \\
\hline $\begin{array}{l}\text { Labor unused } \\
\text { Spring }\end{array}$ & Hours & - & - & 211 \\
\hline Summer & Hours & 26 & 11 & 3 \\
\hline \multicolumn{5}{|l|}{ Capital: } \\
\hline $\begin{array}{l}\text { Investment capital limit } \\
\text { Investment capital unused }\end{array}$ & $\$$ & 29,600 & 29,600 & 29,600 \\
\hline $\begin{array}{l}\text { Investment capital unused } \\
\text { Operating capital used }\end{array}$ & $\$$ & 15682 & 16473 & 16,984 \\
\hline Net revenue: & $\$$ & 16,460 & 15,007 & 14,634 \\
\hline
\end{tabular}


682 to $\$ 16,473$ reflecting the increased operational costs incurred from farming the steeper land.

The similarities of this plan and the Base included: the number of dairy cows, the level of grain feeding, the total acres farmed, the labor utilization, and the complete use of the investment capital. Except for some difference in the acreage of crops grown on the Class II land, the pattern of land utilization of the remaining Land Classes was the same. Four acres of sudan pasture was produced on the Class III land. This was the only plan in which sudan pasture was used. The same restricting resources held for both farm plans, Classes II and III lands and fall labor.

The lack of Class II land was a handicap reflected in increased operational costs and a reduced net revenue. However, the expansion of the land and labor resources and the increased dairy herd size was comparable to the Base Plan and at comparable milk prices the net return from the farm organization was second only to the Base Plan itself.

Differences in Income and Farm Organization With No Owned Class II Land and Corn Grain Production

In the previous plan the lack of owned Class II land was partially overcome by the rental of some Class II land on which corn grain could be produced. However, some farms of the area have to purchase all or nearly all of the grain mixtures that is fed to the dairy cows. The farms that have large grain purchases are apt to be those farms that have little Class II land. In order to test the effect of having to purchase the needed grains, the restriction of no corn grain production was added as an additional restriction to the previous plan of no Class II land.

The effect of not producing corn grain resulted in the purchase of nearly 2,000 bushels of corn. Net revenue was reduced to $\$ 14,634$ as compared to $\$ 16,460$ for the Base Plan (Table 6). In spite of the increased grain purchase costs, the farm organization was expanded to the limits of the land rentals, hired labor, and investment capital.

When corn grain was not produced, wheat replaced oats on the Class II and III lands. The acreage of hay grown on the Class III land was increased substantially thereby maintaining hay sales of over 200 tons. Most of the Class IV land was used for pasture.

The operating capital requirements increased over $\$ 1,300$ as compared to the Base Plan and over $\$ 500$ as compared to the 
comparable plan with corn production as an alternative (Table 6 ). The additional operating capital required, compared to the Base Plan, reflected increased operational costs of the Class III and IV land and the added cost of grain purchases. Compared to the plan which included corn production, most of the increase in operational costs was due mainly to the purchase of grain.

The plan requiring the purchase of corn had a lower net revenue than the Base Plan and the plan permitting corn production. However, the purchase of the needed grain did not eliminate resource expansion or the level of grain feeding. This farm organization ranked third among the large farm plans in the level of net revenue.

\section{Differences in Income and Farm Organization Without Dairy}

\section{Cows}

Dairy cattle as opposed to beef and sheep, was the most profitable livestock enterprise in all of the previous farm plans. To obtain a relative measure of profitability of farm organization without dairying a plan was developed with dairy cattle eliminated as an alternative.

The net revenue of the resulting farm plan fell to $\$ 9,695$ which was $\$ 6,700$ less than the Base Plan (Table 7). The principal revenue sources of this plan were the sale of 3,600 bushels of corn, 480 tons of hay, and off-farm incomes. The livestock consisted of a flock of only 16 sheep. There was enough unused seasonal labor available for a part-time job as a school bus driver. The dairy plan with a net revenue closest to this amount was the $\$ 4.00$ milk price plan with a net revenue of $\$ 10,886$ (Table 4).

As in the dairy farm plans the critical resources were cropland and fall labor. The circumstances that created these shortages were nevertheless different. They were entirely created by the production of crops. Because there was unused labor during the spring and summer seasons, more crops would have been grown for sale if cropland and fall labor could have been obtained. The maximum amount of land was already being rented, and hiring labor that would go unused in seasons other than the fall was unprofitable.

None of the available investment capital was used. The only need for investment capital was for sheep and it was supplied from the off-farm income sources. Most of the investment in physical facilities also went unused as very little silo space and barn space was needed. 
An attempt was made to include beef or sheep in the plan by eliminating the possibility of hay sales and of off-farm work in the winter. The effect of these changes were as follows:

1. No winter work off-farm-the level of crop sales remained high, sheep numbers increased to 67 and net revenue dropped to $\$ 8,144$.

2. No hay sales-the intent of this restriction was to force the feeding of hay. Enough sheep, 150 head, were kept to utilize the existing barn space and eat the hay produced. Grain was sold, and the remainder of the land was rented out. Net revenue, even with high crop yields, fell drastically to $\$ 2,606$. Farmers with average crop yields practically discontinued farming. In fact most of their land was rented out.

In spite of these restrictions the beef enterprise was not profitable and only a modest-sized sheep enterprise was included. It was still more profitable to rent-out land rather than keep beef or a very large number of sheep.

Differences in Income and Farm Organization Without Dairy Cows, Work Off-Farm, Hay Sales or Renting-Out of Land

In an effort to increase the size of the sheep enterprise an additional restriction of not renting-out land was added. Sheep numbers increased by only 15 to 165 head, but net revenue fell to $\$ 2,589$ (Table 8). This was not much less than when land rental was permitted. Net revenue had already dropped below the "poverty level.",

A rather unexpected result was the renting-in of land, and a farm plan based largely on crop sales. Land Class II was rentedin until the marginal value product of the Class II land equaled its marginal cost. Both the rented and the owned Class II land was farmed as intensively as possible, resulting in nearly 2000 bushels of grain sold for cash. The quantity of corn grain produced and sold indicates the relative profitability of grain sales to beef and sheep production. Corn production was expanded through land rental until the marginal value of Class II land equaled its rental cost. The only means available to recover the costs of the hay that had been produced as a part of the rota-

\footnotetext{
${ }^{21}$ Persons considered to be living in poverty are those in families with net cash incomes of less than $\$ 3,000$. " Source: Alan R. Bird, Poverty in Rural A reas of the United States, (Washington: U. S. Department of Agriculture, Resource Development Economics Division, Agricultural Economics Report No. 63, November, 1964), p. 1.
} 
TABLE $y$

Optimum Farm Plans, Large Farms, All Alternatives Considered Except No Dairy Cows Compared to the Base Plan

\begin{tabular}{|c|c|c|c|}
\hline Item & Unit & $\begin{array}{l}\text { Base } \\
\text { Plan }\end{array}$ & $\begin{array}{c}\text { Plan Without } \\
\text { Dairy Cows }\end{array}$ \\
\hline \multicolumn{4}{|l|}{ Livestock: } \\
\hline \multicolumn{4}{|l|}{$\begin{array}{l}\text { Dairy cows ( } 1 \mathrm{lb} . \\
\text { grain } / 4.75 \mathrm{lbs} . \text { milk) }\end{array}$} \\
\hline Dairy replacements, raised & Head & 14 & - \\
\hline Ewes & Head & - & 16 \\
\hline \multicolumn{4}{|l|}{ Land: } \\
\hline Owned & Acres & 216 & 216 \\
\hline Whole farm rented in & Acres & 108 & 108 \\
\hline Class II only rented in & Acres & 40 & 40 \\
\hline \multicolumn{4}{|l|}{ Crops: } \\
\hline \multicolumn{4}{|l|}{ Class II land } \\
\hline Corn, 2 yr. & Acres & 11 & 25 \\
\hline Corn silage, 2 yr. & Acres & 14 & $\overline{19}$ \\
\hline Oats & Acres & 12 & 12 \\
\hline Wheat & Acres & - & $\overline{c 0}$ \\
\hline Alfalfa hay, 5 yr. & Acres & 63 & 63 \\
\hline \multicolumn{4}{|l|}{ Class III land } \\
\hline Oats & Acres & $\begin{array}{l}8 \\
8\end{array}$ & $\begin{array}{l}8 \\
8\end{array}$ \\
\hline Alfalfa hay, 6 yr. & Acres & 48 & 48 \\
\hline \multicolumn{4}{|l|}{ Class IV land } \\
\hline Corn silage, 1 yr. & Acres & 1 & 1 \\
\hline Wheat & Acres & 1 & 6 \\
\hline Alfalfa hay, $7 \mathrm{yr}$. & Acres & 7 & 44 \\
\hline Unimproved pasture & Acres & 66 & 24 \\
\hline \multicolumn{4}{|l|}{ Class VI unimproved } \\
\hline pasture & Acres & 65 & 65 \\
\hline Class VII idle & Acres & 60 & 60 \\
\hline \multicolumn{4}{|l|}{ Crop purchases or sales: } \\
\hline Corn equivalent sales & Bushels & - & 3,670 \\
\hline Hay sales & Tons & 263 & 484 \\
\hline \multicolumn{4}{|l|}{ Labor: } \\
\hline Total available labor & Hours & 7,539 & 4,634 \\
\hline Operator and family & Hours & 4,634 & 4,634 \\
\hline Full-time hired & Hours & 2,905 & \\
\hline Work off-farm-winter & Hours & 421 & 780 \\
\hline \multicolumn{4}{|l|}{ Labor unused } \\
\hline Spring & Hours & - & 149 \\
\hline Summer & Hours & 26 & 246 \\
\hline \multicolumn{4}{|l|}{ Capital: } \\
\hline Investment capital limit & $\$$ & 29,600 & 29,600 \\
\hline Investment capital unused & $\$$ & & 29,600 \\
\hline Operating capital used & $\$$ & 15,682 & 11,907 \\
\hline Net revenue: & $\$$ & 16,460 & 9,695 \\
\hline
\end{tabular}


tional requirements was to feed it to livestock. The ration requirements of the livestock were fixed so that some corn silage had to be fed along with the hay. Therefore, just enough corn silage was grown to meet the ration requirements of the livestock and to utilize completely the hay which had been produced. In order to recover the cost of the hay production it was profitable to expand the sheep numbers by 15 .

All of the Class III, IV, and VI lands was pastured. Some supplementary feeding of ensilage during the pasture season was required. More than enough May-June pasture was unused to satisfy the supplementary feed needed in the late summer. To have taken advantage of this surplus, it would have been necessary to harvest and store it.

There was adequate unused labor in all seasons so that one person could have been employed off the farm at a full-time, 40hour-per-week job. Labor used off-farm in this manner might leave the winter lambing season with a tight labor schedule. Offfarm work offered the best means of increasing the net revenue with these restrictions. Even in this extreme situation it was not profitable for beef to be included in the farm plan.

Differences in Income and Farm Organization with Beef Cattle in the Farm Plan

In order to study a farm plan which included beef cattle, all of the previous non-dairy restrictions were maintained plus an additional restriction of not including sheep. The resulting plan had a net revenue of only $\$ 1,934$ (Table 8). This was $\$ 650$ less than the sheep farm plan. The beef enterprise consisted of 24 brood cows and the sale of 18 head of yearling grass-fat steers. Nearly 2,500 bushels of cash grains were also produced and sold.

The cropping program was nearly indentical to the cropping program of the sheep plan. A few more acres of Class II land were rented-in for cash grain cropping purposes. The land rental ceased when the rental cost equaled the revenue of products sold. As was the case with the sheep farm organization the cost of producing the hay was recovered by feeding the hay to the beef animals, and ration requirements of the beef animals also required a fixed amount of corn silage. Therefore, the quantity of corn harvested as ensilage was just the amount of corn needed to completely utilize the hay that had been produced.

As with the sheep farm plan there was sufficient excess labor in all seasons so that one person would have worked off the farm 
TABLE 8

Optimum Farm Plans, Large Farms, All Alternatives Except No Dairy Cows, No Work Off-Farm, No Hay Sales or No Renting-Out of Land Compared to the Base Plan

\begin{tabular}{|c|c|c|c|c|}
\hline \multirow[b]{2}{*}{ Item } & \multirow[b]{2}{*}{ Unit } & \multirow{2}{*}{$\begin{array}{l}\text { Base } \\
\text { Plan }\end{array}$} & \multicolumn{2}{|c|}{ Plans with } \\
\hline & & & Sheep & Beef \\
\hline
\end{tabular}

Livestock:

Dairy cows ( $1 \mathrm{lb}$.

grain/4.75 lbs. milk) Head

Dairy replacements, raised Head

Ewes

Beef cows

Head

Land:

Owned

Whole farm rented in

Head

Class II only rented in

Acres

Acres

Acres

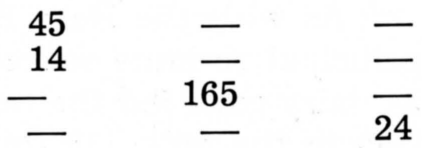

Crops:

Class II land

Corn, 2 yr.

Corn silage, 2 yr.

Acres

Acres

Oats

Acres

Wheat

Acres

Alfalfa hay, 5 yr. ,

Acres

Clover-timothy hay, 2 yr. Acres

216

216

216

108

40

15

Class III land

Corn, 1 yr.

Acres

Oats

Acres

Alfalfa hay, $6 \mathrm{yr}$.

Acres

Improved pasture

Idle

Acres

Acres

11

14

12

$\overline{63}$

Class IV land

Acres

Corn silage, 1 yr.

Wheat

Acres

Alfalfa hay, $7 \mathrm{yr}$.

Unimproved pasture

Acres

Acres

$\overline{11}$

Class VI unimproved

pasture

Class VII idle

Acres

Acres

65

60

19

21

6

6

Crop purchases or sales:

Corn equivalent sales

Hay sales

Bushels

Tons

$\overline{263}$

Labor:

Total available labor

Operator and family

Full-time hired

Work off-farm-winter

Labor unused

Winter

Spring

Summer

Fall

Hours

7,539

Hours

Hours

Hours

4,634

2,905

421

Hours

Hours

Hours

Hours

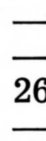

1,235

919

628

523

43

43

40

Capital:

Investment capital limit \$

Investment capital unused \$

Operating capital used

$\$$
$\$$
$\$$

29,600

29,600

29,600

$15, \overline{82}$

24,252

23,540

Net revenue:

$2,589 \quad 1,934$


full-time. A full-time job was a better alternative than either raising beef or sheep under conditions of this study.

\section{Base Plan}

\section{SMALL FARM}

As with the Base Plan of the large farm, the small farm's principal revenue source was the milk produced and sold from 24 dairy cows fed the heaviest grain-milk ratio (1:4.75). In addition to the milk 115 tons of surplus hay was sold, along with a small amount of corn. A few hours of labor were worked off-farm during the winter. The net revenue of the farm organization was $\$ 10,019$ (Table 9).

In addition to the owned land 21 acres of Class II land and 54 acres of land with a Land Class distribution similar to the owned land were rented-in and farmed. The rental of Class II land was the maximum permitted. "Whole-farm" land rental was not quite expanded to its limit due to a shortage of spring and fall labor. This was true even though $\mathbf{5 4 0}$ hours of part-time year around labor had been employed.

All of the grain and hay crops were grown on the Class II and Class III land. The rotation followed was extensive rather than intensive and quite similar to that on the Base Plan of the large farm. Land Classes IV and VI were pastured and Land Class VII remained idle. Supplementary feeding of 19,000 pounds of silage T.D.N. was necessary during the late pasture season.

In order to house the 24 dairy cows it was necessary to add nine stanchions to the existing barn. The silo capacity was expanded by 91 tons. These expansions along with the purchase of additional cows used all but $\$ 2,046$ of the available investment capital.

The limiting resources were Class II land rental, and fall and spring labor. Even with more of these resources, the unused "whole-farm" and rental and investment capital would have permitted only a slightly larger farm operation.

Differences in Income and Farm Organization with Average Crop Yields

A principal difference other than resource quantities between the large and small farms was in crop production costs. Compared to the large farms, the small farms had higher crop production costs for most of the crops produced, but the yield levels in the Base situations for both were assumed above the 
TABLE 9

Optimum Farm Plans, Small Farms, All Alternatives Considered, $\$ 5.00$ Milk

\begin{tabular}{|c|c|c|c|}
\hline \multirow[b]{2}{*}{ Item } & \multirow[b]{2}{*}{ Unit } & \multicolumn{2}{|c|}{ Level of Corn Yields } \\
\hline & & $\begin{array}{c}\text { High } \\
\text { (Base) }\end{array}$ & Average \\
\hline \multicolumn{4}{|l|}{ Livestock: } \\
\hline \multicolumn{2}{|l|}{ Dairy cows $(1 \mathrm{lb}$} & 24 & 22 \\
\hline Dairy replacements, raised & Head & 8 & 7 \\
\hline \multicolumn{4}{|c|}{$\begin{array}{l}\text { Dairy replacements, ralseu neau } \\
\text { Land: }\end{array}$} \\
\hline Owned & Acres & 113 & 113 \\
\hline Whole farm rented in & Acres & 54 & 57 \\
\hline $\begin{array}{l}\text { Class II only rented in } \\
\text { Crops: }\end{array}$ & Acres & 21 & - \\
\hline \multicolumn{4}{|l|}{ Crops: } \\
\hline $\begin{array}{l}\text { Cliass II land } \\
\text { Corn, } 2 \text { yr. }\end{array}$ & & & \\
\hline $\begin{array}{l}\text { Corn, } 2 \text { yr. } \\
\text { Corn silage, } 2 \text { yr. }\end{array}$ & $\begin{array}{l}\text { Acres } \\
\text { Acres }\end{array}$ & 7 & $\begin{array}{r}4 \\
13\end{array}$ \\
\hline $\begin{array}{l}\text { Corn silage, } 2 \text { yr. } \\
\text { Oats }\end{array}$ & $\begin{array}{l}\text { Acres } \\
\text { Acres }\end{array}$ & 7 & $\begin{array}{r}10 \\
4\end{array}$ \\
\hline Wheat & Acres & - & 4 \\
\hline Alfalfa hay, 5 yr. & Acres & 38 & - \\
\hline Clover-timothy hay, $1 \mathrm{yr}$. & Acres & 2 & 8 \\
\hline \multicolumn{4}{|c|}{ Class III land } \\
\hline Corn, 1 yr. & Acres & 4 & 4 \\
\hline Oats & Acres & 4 & 4 \\
\hline Alfalfa hay, 6 yr. & Acres & 25 & 25 \\
\hline \multicolumn{4}{|l|}{ Class IV land } \\
\hline Wheat & Acres & 二 & $\begin{array}{r}3 \\
29\end{array}$ \\
\hline Alfalfa hay, 7 yr. & Acres & $\overline{39}$ & $\begin{array}{l}22 \\
14\end{array}$ \\
\hline Unimproved pasture & Acres & 39 & \\
\hline \multicolumn{3}{|l|}{ Class VI unimproved } & \\
\hline $\begin{array}{l}\text { pasture } \\
\text { Class VII idle }\end{array}$ & Acres & 31 & 31 \\
\hline \multicolumn{4}{|l|}{ Crop purchases or sales: } \\
\hline Corn equivalent sales & Bushels & 9 & - \\
\hline Corn equivalent purchases & Bushels & $\overline{-}$ & 446 \\
\hline Hay sales & Tons & 115 & - \\
\hline Hay purchases & Tons & 一 & 2 \\
\hline \multicolumn{4}{|l|}{ Labor: } \\
\hline Total available labor & Hours & $\begin{array}{l}4,182 \\
3.642\end{array}$ & $\begin{array}{l}3,042 \\
3,642\end{array}$ \\
\hline $\begin{array}{l}\text { Operator and family } \\
\text { Part-time, year around }\end{array}$ & Hours & & \\
\hline hired & Hours & 540 & - \\
\hline Work off-farm-winter & Hours & 73 & - \\
\hline Labor unused-summer & Hours & 159 & 42 \\
\hline \multicolumn{4}{|l|}{ Capital: } \\
\hline Investment capital limit & $\$$ & 16,600 & 16,600 \\
\hline Investment capital unused & $\$$ & 2,046 & 2,952 \\
\hline Operating capital used & $\$$ & 8673 & 6,459 \\
\hline Net revenue: & $\$$ & 10,019 & 7,863 \\
\hline
\end{tabular}


area averages. A reduction of the crop yields on the small farm to area averages would further increase per unit costs of crop production and reduce net revenue still further.

When crop yields were reduced to area averages, net revenue decreased from $\$ 10,019$ to $\$ 7,863$ (Table 9 ). The farm was operated with 22 rather than 24 dairy cows. In this situation, it was necessary to purchase feed rather than have surplus crops for sale. Two tons of hay and 446 bushels of corn grain were purchased. The reduced dairy cow numbers and added feed costs explain a substantial part of the net revenue difference between the low and high crop yield farms.

The average-yield farm was operated with only the family labor supply. The maximum "whole-farm" land was rented, but no Class II land by itself was rented. The crop rotation was intensified on owned Class II land to the shortest possible by a change from five-year alfalfa hay to one-year clover-timothy hay.

There was ample investment capital available for further expansion of the dairy herd, but additional land and labor were needed. Before additional expansion could take place, therefore, it would be necessary to increase crop yields by adopting recommended practices, thus making it profitable to operate more land and hire more labor.

\section{Differences in Income and Farm Organization with $\$ 4.00$}

\section{Milk Price}

The 24-cow dairy herd of the Base Plan represented more than a 50 per cent increase in herd size over the reported herd size of the small farms. The stability of the dairy enterprise was shown by reducing the price of milk and observing the effects of the price reduction.

With a $\$ 4.00$ per hundredweight milk price, there was less emphasis on dairy production and more emphasis upon crop production than in the Base Plan. The reduction in milk price did not affect the level of grain feeding, but it did affect the cow numbers and net revenue. Only 17 dairy cows were kept as compared to 24 in the Base Plan, and net revenue fell from $\$ 10,019$ to $\$ 7,420$ (Table 10). Fewer cows were kept because further building expansion was unprofitable. Existing barn space was remodeled to add two more cows, but any expansion beyond this would have reduced net revenue by $\$ 20.76$ for each additional cow.

With fewer cows, it became profitable to raise more crops for sale. Thus maximum amounts of land were rented-in. Crops 
TABLE 10

Optimum Farm Plans, Small Farm, All Althernatives Considered with $\$ 4.00$ and $\$ 6.00$ Milk Compared to the $\$ 5.00$ Milk Base Plan

Plans With Milk Prices of:

Item

Unit

$\$ 4.00$

$\$ 5.00$

$\$ 6.00$

(Base)

Livestock:

Dairy cows ( $1 \mathrm{lb}$.

grain/4.75 lbs. milk) Head

Dairy replacements, raised Head

Land:

Owned

Whole farm rented in

Class II only rented in

17

5

24

25

Crops:

Class II land

Corn, 2 yr.

Corn silage, $2 \mathrm{yr}$.

Oats

Wheat

Alfalfa hay, $5 \mathrm{yr}$.

Clover-timothy hay, 1 yr. Acres

Class III land

Corn, 1 yr.

Oats

Alfalfa hay, 6 yr.

Class IV land

Wheat

Alfalfa hay, $7 \mathrm{yr}$.

Unimproved pasture

Class VI unimproved

pasture

Class VII idle

Crop sales:

Corn equivalent sales

Hay sales

Labor:

Total available labor

Operator and family

Part-time, year around hired

Work off-farm-winter

Labor unused-summer

Capital:

Investment capital limit

Investment capital unused

Operating capital used

Net revenue:

Acres

Acres

Tons

Hours

Hours

Hours

Hours

Hours
Acres

Acres

Acres

Acres

Acres

Acres

Acres

Acres

Acres

Acres

Acres

Acres

Acres

Acres

113

57

21

113

54

21

113

36

21

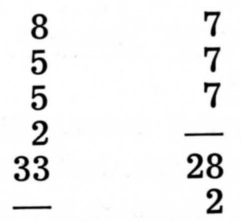

8

9

4

4

20

4

$\begin{array}{rrr}4 & 4 & 4 \\ 4 & 4 & 4 \\ 25 & 25 & 22\end{array}$

Bushels $\quad 507$

160

115

76

3,642

4,182

4,158

3,642

3,642

3642

$2 \overline{230}$

540

516

30

73

159

167

\begin{tabular}{lrrr}
$\$$ & 16,600 & 16,600 & 16,600 \\
$\$$ & 8.961 & 2,046 & 271 \\
$\$$ & 7,501 & 8,673 & 8,315 \\
$\$$ & 7,420 & 10,019 & 13,259 \\
\hline
\end{tabular}


were grown on Land Classes II and III, as well as on a small acreage of Land Class IV. Hay sales increased by 45 tons and grain sales by 500 bushels as compared to the Base Plan. If more land had been available undoubtedly more crops would have been produced. The additional return per acre for Class II land was $\$ 48.24$ and for Class III land $\$ 27.07$ per acre.

The reduced dairy herd and increased crop acreage redistributed the seasonal labor demands so that only family labor was needed to meet labor requirements. The 230 hours of surplus winter labor were worked off-farm. Only 30 hours of summer labor were unused.

The decreased dairy herd size left substantially more investment capital unused than in the Base Plan. Over 50 per cent of the investment capital was unused compared to 12 per cent in the Base Plan.

\section{Differences in Income and Farm Organization with $\$ 6.00$ Milk Price}

The small quantities of unused resources with the $\$ 5.00$ milk price Base Plan left little room for additional dairy expansion with further milk price increases; nevertheless some additional organizational changes were possible. The nature and extent of such changes were observed by increasing the price of milk to $\$ 6.00$.

With $\$ 6.00$ milk, net revenue was $\$ 13,529$ compared with $\$ 10,019$ in the Base Plan (Table 10). Ninety-six per cent of the increased revenue was due to the higher price. Slight organizational changes were made. The major one was increased emphasis upon the dairy enterprise and less on crop sales.

Increased emphasis upon dairy production was shown by the addition of one more cow and the elimination of the off-farm winter work as compared to the Base Plan. Less emphasis upon crop production was indicated by the reduction in the acres of "whole-farm" land rented-in. As a result of the decrease in acres rented, fewer acres of crops were grown, the quantity of hired labor decreased, and there was less surplus hay to sell.

A slight rearrangement of the crop rotation of Class II land became profitable with the increased milk price. All grain was fed and less hay was sold. Alfalfa acreage was reduced by eight acres and clover-timothy hay was increased by two acres as compared to the Base Plan. This shift in hay acreage permitted a four-acre increase in corn, and increased small grain by one acre. 
Wheat made up half of the small grain acreage. The additional corn grain and small grain were used in the dairy ration. Additional silage was needed as a supplement for the reduced pasture acreage on Classes IV and VI land.

Fall, winter, and spring labor supplies were completely used as well as $\mathbf{5 1 6}$ hours of year around part-time help. The fall labor shortage was more critical than the winter or spring shortage. Even if additional labor could have been hired, more land would have been needed for further dairy expansion. The only unused land was 21 acres of "whole-farm" rented-in as the limit on Class II land rental had been reached. Also there was only $\$ 271$ of unused investment capital available for further expansion. In other words all available resources for expansion were practically exhausted. Further expansion without substantial additional resources was impossible.

Differences in Income and Farm Organization When Restricted to No Resource Expansion and No Work Off-Farm

Each of the previous plans of the small farm were based on the possibility of expanding land and labor resources. Even with the possibility of expanding resources some farmers continue their operations at the same resource levels. Various reasons such as age and uncertainty may account for this hesitancy to expand. A comparision of the net revenue associated with the resource expansion of the Base Plan with the continuation at present resource levels could dispell some of the uncertainty. The restriction of no off-farm work was added to insure the continuation of farming as the main income source.

Not permitting expansion of land and labor resources did not limit dairy expansion or net revenue as much as expected. Compared to the Base Plan cow numbers were down only from 24 to 22 and net revenue from $\$ 10,019$ to $\$ 9,184$ (Table 11). Compared to the same resource situation on the large farm (Table $5)$, there was a relatively larger dairy herd and less decline in net revenue on the small farm.

Reducing the availability of hired labor and additional land resulted in some changes in land use and in the purchase of feeds. No corn grain was produced and most of the needed grain was purchased. Some corn silage was produced on land Class II, III, and IV. About half of the Class VII land was pastured. The farm organizations with restricted land expansion were the only plans that used any Class VII land as pasture. The shortage of 
pasture was evidenced by the fact that there was no May-June pasture surplus and that 27,900 pounds of ensilage T.D.N. were used as summer pasture supplement. The production and sale of

\section{TABLE 11}

Optimum Farm Plans, Small Farms, \$5.00 Milk, All Alternatives Considered Except No Land Rentals, No Hired Labor and No Work Off-Farm Compared to the Base Plan

\begin{tabular}{|c|c|c|c|c|}
\hline \multirow[b]{2}{*}{ Item } & \multirow[b]{2}{*}{ Unit } & \multirow[b]{2}{*}{$\begin{array}{l}\text { Base } \\
\text { Plan }\end{array}$} & \multicolumn{2}{|c|}{$\begin{array}{l}\text { Plans Without } \\
\text { Expansion and } \\
\text { Dairy Cows Fed }\end{array}$} \\
\hline & & & $\begin{array}{c}\text { Grain } \\
\text { \& Forage }\end{array}$ & $\begin{array}{c}\text { All } \\
\text { Forage }\end{array}$ \\
\hline \multicolumn{5}{|l|}{ Livestock: } \\
\hline \multicolumn{5}{|l|}{ Dairy cows ( $1 \mathrm{lb}$. } \\
\hline Dairy replacements, raised & Head & 8 & 7 & 8 \\
\hline \multicolumn{5}{|c|}{ Land: } \\
\hline Owned & Acres & 113 & 113 & 113 \\
\hline Whole farm rented in & Acres & 54 & - & - \\
\hline Class II only rented in & Acres & 21 & - & - \\
\hline \multicolumn{5}{|l|}{ Crops: } \\
\hline \multicolumn{5}{|l|}{ Class II land } \\
\hline Corn, 2 yr. & Acres & 7 & - & 7 \\
\hline Corn silage, 2 yr. & Acres & 7 & 5 & - \\
\hline Oats & Acres & 7 & 3 & - \\
\hline Wheat & Acres & - & - & 3 \\
\hline Alfalfa hay, 2 yr. & Acres & - & - & 3 \\
\hline Alfalfa hay, 5 yr. & Acres & 28 & 13 & 8 \\
\hline Clover-timothy hay, 1 yr. & Acres & 2 & - & - \\
\hline \multicolumn{5}{|c|}{ Class III land } \\
\hline Corn, 1 yr. & Acres & 4 & - & - \\
\hline Corn silage, 1 yr. & Acres & 一 & 3 & 3 \\
\hline Oats & Acres & 4 & 3 & - \\
\hline Wheat & Acres & - & - & 3 \\
\hline Alfalfa hay, 6 yr. & Acres & 25 & 16 & 16 \\
\hline \multicolumn{5}{|l|}{ Class IV land } \\
\hline Corn silage, 1 yr. & Acres & - & 2 & 2 \\
\hline Wheat & Acres & - & 2 & 2 \\
\hline Alfalfa hay, 7 yr. & Acres & - & 11 & 12 \\
\hline Improved pasture & Acres & - & - & 10 \\
\hline Unimproved pasture & Acres & 39 & 11 & - \\
\hline \multicolumn{5}{|l|}{ Class VI unimproved } \\
\hline pasture & Acres & 34 & 23 & 23 \\
\hline $\begin{array}{l}\text { Class VII idle } \\
\text { Unimproved pasture }\end{array}$ & Acres & 31 & $\begin{array}{l}11 \\
10\end{array}$ & $\overline{21}$ \\
\hline & 40 & & & \\
\hline
\end{tabular}


Crop purchases or sales:

Corn equivalent sales

Corn equivalent purchases Bushels

Hay sales

Labor:

Total

Operator

Part-time, year around hired

Work off-farm-winter

Labor unused

Spring
Summer
Fall

Capital:

Fall

Investment capital limit $\$$

Investment capital unused $\$$

Operating capital used

Net Revenue:

Tons

$\begin{array}{rr}\frac{9}{115} & 1,062 \\ 57\end{array}$

184

Hours

\section{4,182}

3,642

Hours

3,642

3,642

3,642

Hours

Hours

540

73

Hours

Hours

$\overline{159}$

31

48

Hours

64

81

16

\begin{tabular}{lrrr}
$\$$ & 16,600 & 16,600 & 16,600 \\
$\$$ & 2.046 & 2,844 & 1,605 \\
$\$$ & 8,673 & 6,915 & 5,506 \\
$\$$ & 10,019 & 9,184 & 6,630 \\
\hline
\end{tabular}

57 tons of hay was more than adequate to pay for the 1,062 bushels of purchased corn.

The cropping program made maximum use of the family labor supply. All of the winter and fall labor was used and only a small amount of spring and summer labor was left unused.

Differences in Income and Farm Organization if Restricted to No Resource Expansion, No Work Off-Farm, and All-Forage Fed Cows

Just as the restriction of no expansion of the land and labor resources limits the number of dairy cows that can be kept, the restriction of an all-forage dairy ration limits the amount of milk that is produced per cow. The purpose of the all-forage ration was to compare the profitability of dairy cows fed such a ration with either the dairy cows fed a grain ration and/or the other classes of forage consuming livestock. Limiting the dairy herd to an all-forage ration caused a reduction in milk and net returns. Dairy cow numbers were one greater than the preceding plan but one less than in the Base Plan. As compared to the previous plan, operating capital requirements were less by $\$ 1,409$, and the net revenue was $\$ 2,554$ less. Compared to the Base Plan net revenue dropped from $\$ 10,019$ to $\$ 5,530$ (Table 11 ).

The most surprising feature of this organization was that every acre of land, even all the Class VII land, was utilized. The shortage of land and winter labor resources stopped further 
expansion of the dairy herd. Land, however, was the more critical resource.

The relative shortage of land was evidenced further by the lack of surplus May-June pasture. Ten acres of the Class IV pasture were improved, one of the few instances in which permanent pasture improvement was profitable.

Even with additional land and winter labor, expansion of the operation would not have been very great since the quantities of unused spring, summer, and fall labor were only 48, 81, and 16 hours, respectively. Also, there was only $\$ 1,605$ of unused investment capital. These resources would not have allowed more than two more cows.

The crop rotations on each of the Land Classes were extensive except for the two-year corn silage and three acres of twoyear alfalfa on the Class II land.

The adjustments to overcome the handicap of being unable to feed dairy cows grain was substantial but woefully inadequate to offset the effect of the lower milk production from all-forage rations. However, even plans with dairy cows fed all-forage rations had higher net revenues than the beef or sheep enterprises.

Differences in Income and Farm Organization with No Owned Class II Land and No Part-Time Job

The purpose of considering a farm plan with no Class II land was to simulate conditions that prevail on some area farms. The disadvantages of not having Class II land could be partially off-set through renting some land. In order to insure that the main income source would be from farming, the alternative of part-time work was eliminated.

The elimination of all owned Class II land from the farm decreased net revenue by only $\$ 578$ when compared to the Base Plan (Table 12). Under this restriction a maximum of "wholefarm" land was rented-in and grain was purchased. The net revenue was the result of sale of milk from 25 cows and 82 tons of hay. One more cow was kept and the same grain-milk ratio was fed as in the Base Plan, even though it was necessary to purchase 489 bushels of corn.

Crop production was confined to Class II and III land. Additional quantities of Class II and Class III lands could have been profitably utilized. Land Classes IV and VI were used for pasture. In spite of having 85 acres of pasture it was necessary to supplement the pasture during the late summer with 17,300 pounds of 
Optimum Farm Plans, Small Farms, \$5.00 Milk, All Alternatives Considered Except No Owned Class II Land, and No Part-Time Job Compared to the Base Plan

\begin{tabular}{|c|c|c|c|c|}
\hline \multirow[b]{2}{*}{ Item } & \multirow[b]{2}{*}{ Unit } & \multirow[b]{2}{*}{$\begin{array}{l}\text { Base } \\
\text { Plan }\end{array}$} & \multicolumn{2}{|c|}{$\begin{array}{l}\text { Plans With } \\
\text { Corn Grain }\end{array}$} \\
\hline & & & Raised & $\begin{array}{c}\text { Pur- } \\
\text { chased }\end{array}$ \\
\hline \multicolumn{5}{|l|}{ Livestock: } \\
\hline $\begin{array}{l}\text { Dairy cows ( } 1 \mathrm{lb} . \\
\text { grain } / 4.75 \mathrm{lbs} . \text { milk) }\end{array}$ & Head & 24 & 25 & 25 \\
\hline Dairy replacements, raised & Head & 8 & 8 & 8 \\
\hline \multicolumn{5}{|c|}{ Land: } \\
\hline Owned & Acres & 113 & 113 & 113 \\
\hline Whole farm rented in & Acres & 54 & 57 & 17 \\
\hline Class II only rented in & Acres & & & 21 \\
\hline \multicolumn{5}{|l|}{ Crops: } \\
\hline \multicolumn{5}{|l|}{ Class II land } \\
\hline $\begin{array}{l}\text { Corn, } 2 \text { yr. } \\
\text { Corn silage, } 2 \text { yr. }\end{array}$ & Acres & 7 & 8 & 6 \\
\hline Oats & Acres & 7 & 5 & - \\
\hline Wheat & Acres & 7 & - & 3 \\
\hline Alfalfa hay, 5 yr. & Acres & 28 & 15 & 15 \\
\hline Clover-timothy hay, $1 \mathrm{yr}$. & Acres & 2 & 2 & - \\
\hline \multicolumn{5}{|c|}{ Class III land } \\
\hline Corn, 1 yr. & Acres & 4 & 5 & - \\
\hline Corn silage, $1 \mathrm{yr}$. & Acres & - & $\overline{5}$ & 3 \\
\hline Oats & Acres & 4 & 5 & - \\
\hline Wheat & Acres & $\overline{25}$ & $\overline{39}$ & 5 \\
\hline Alfalfa hay, 6 yr. & Acres & 25 & 32 & 28 \\
\hline Class IV land & & 39 & 54 & 42 \\
\hline $\begin{array}{l}\text { Unimproved pasture } \\
\text { Class VI unimproved }\end{array}$ & Acres & 39 & 34 & 42 \\
\hline pasture & Acres & 34 & 34 & 26 \\
\hline Class VII idle & Acres & 31 & 31 & 24 \\
\hline \multicolumn{5}{|l|}{ Crop purchases or sales: } \\
\hline Corn equivalent sales & Bushels & 9 & 一 & 一 \\
\hline $\begin{array}{l}\text { Corn equivalent } \\
\text { purchases }\end{array}$ & & & & \\
\hline $\begin{array}{l}\text { purchases } \\
\text { Hay sales }\end{array}$ & Bushels & $\overline{115}$ & 489 & 1,155 \\
\hline $\begin{array}{l}\text { Hay sales } \\
\text { Labor: }\end{array}$ & Tons & \multicolumn{3}{|c|}{ Labor: } \\
\hline $\begin{array}{l}\text { Labor: } \\
\text { Total available labor }\end{array}$ & Hours & 4,182 & 4,161 & 4,117 \\
\hline Operator and family & Hours & 3,642 & 3,642 & 3,642 \\
\hline $\begin{array}{l}\text { Part-time, year around } \\
\text { hired }\end{array}$ & & & & \\
\hline hired & Hours & 540 & 519 & 475 \\
\hline Work off-farm-winter & Hours & 73 & - & - \\
\hline \multicolumn{5}{|l|}{ Labor unused } \\
\hline $\begin{array}{l}\text { Spring } \\
\text { Summer }\end{array}$ & $\begin{array}{l}\text { Hours } \\
\text { Hours }\end{array}$ & $\overline{158}$ & $\begin{array}{r}9 \\
140\end{array}$ & 117 \\
\hline \multirow{2}{*}{\multicolumn{5}{|c|}{ Capital: }} \\
\hline & & 16,600 & & \\
\hline $\begin{array}{l}\text { Investment capital umit } \\
\text { Investment capital unused }\end{array}$ & $\$$ & 2,046 & 538 & 581 \\
\hline Operating capital used & $\$$ & 8,673 & 9,017 & 8,736 \\
\hline Net revenue: & $\$$ & 10,019 & 9,441 & 9,038 \\
\hline
\end{tabular}


T.D.N. from corn silage. There was more unused May-June pasture than the supplementary feeding represented. If the pasture had been harvested, or some of the sold hay used as supplementary feed, then the ensilage would not have been needed. All Class VII land was unused.

All of the winter and fall labor was used including 519 hours of year around hired part-time help. Only nine hours of spring labor and 140 hours of summer labor were unused.

If the shortage of cropland and labor had not limited the dairy herd expansion to 25 cows in this plan, the amount of investment capital soon would have become restrictive. Only $\$ 538$ of investment capital remained unused, an amount sufficient to add another cow.

The requirements for operating capital were increased by higher machine costs, land rental, and feed purchases resulting in the use of the largest quantity of operational capital of any of the small farm plans. However, the net revenue figure was the second largest for any of the small farm plans in which the milk price was $\$ 5.00$.

Differences in Income and Farm Organization with No Owned Class II Land, No Corn Grain Production and No Part-Time Job

For various reasons some farmers of the area purchase most of the grain needed in dairy ration. One reason for the grain purchases was a shortage of suitable cropland, particularly Class II land, to produce the quantity of corn needed for grain and silage purposes. The additional constraint of no corn grain production was added to the previous restrictions of no owned Class II land, and no-part-time job, to determine whether grain purchases would be more profitable than an all-forage ration.

Not allowing corn grain to be produced resulted in the purchase of most of the grain needed to feed the dairy cows. The resulting net income was $\$ 9,038$, almost $\$ 1,000$ less than the Base Plan, but the grain shortage did not curtail the dairy expansion, (Table 12). One more cow was added to the dairy herd than in the Base Plan. The grain-milk ratio remained unchanged in spite of purchasing most of the needed grains. Hay sales were 50 tons less than in the Base Plan but the revenue from hay sales considerably exceeded the cost of the 1,155 bushels of purchased grains.

The amount of land rented was the least amount in any of the small farm dairy plans. All of the Class II land that could be 
rented alone was rented. Crop production was concentrated on Classes II and III and with a slightly greater proportion of the land in corn silage and wheat production. Corn silage was used as a winter feed and summer pasture supplement. The seeding of wheat, the harvest of hay and silage, and the expanded dairy herd used all the family winter and fall labor and 475 hours of year-round part-time help. There were 117 hours of unused labor during the spring season and 169 hours during the summer season.

More of the investment capital was used than in the Base Plan. Only $\$ 581$ of investment capital remained unused. Even if additional land and labor had been available, dairy expansion could not have been carried much further.

There was little difference in this plan and the one without owned Class II land (Table 12). Net revenue was down $\$ 400$ mainly because 666 more bushels of grain were purchased and less land was farmed. Dairy herd sizes were the same and there were only minor differences in cropping patterns. Given the opportunity to expand the land and labor resource bases in these two plans, dairy herd expansion followed, and the net result of such expansions were not greatly different.

\section{Differences in Income and Farm Organization Without Dairy Cows}

When milk production was included as an enterprise alternative on farms of both sizes, it was the main source of income, even at a milk price of $\$ 4.00$ per hundredweight. In order to examine other types of organizations dairy cows were eliminated as an alternative.

Eliminating dairy cows reduced the net revenue to $\$ 5,785$ from the Base Plan net revenue of $\$ 10,019$, a 40 per cent decrease (Table 13). The principal revenue sources were grain and hay sales, the part-time job, and sale of wool and lambs from 14 ewes.

The maximum amount of land was rented. The rotation was extensive, except for the two-year corn grown on the Class II land. The grain crops produced were corn and wheat. The hay crop was alfalfa. One acre of silage was needed to feed the sheep. Except for a small quantity of grain and hay needed for the sheep, the crops were all sold. Crop sales consisted of 1,951 bushels of corn equivalent and 277 tons of hay.

Cropland was the only limiting resource. All of the Class VI land was used for pasture. No summer supplementary feeding 
was required. There was surplus labor in all seasons. The family labor supply was adequate for all non-dairy plans. None of the investment capital was used. The investment capital needed for sheep was furnished from the part-time job.

The basic farm organization was a part-time farm in the winter and a cash crop farm during the summer. The elimination of the dairy alternative resulted in a plan almost without livestock.

Since livestock was the primary user of winter labor it was decided to eliminate the alternatives of hourly winter work offfarm, and the part-time job. The elimination of these alternatives resulted in 1,100 hours of unused winter labor, increased sheep numbers to 35 head, left crop sales almost unchanged, but net revenue dropped to $\$ 4,034$. Crop sales continued to be a more important source of revenue than livestock sales.

Differences in Income and Farm Organization Without Dairy Cows, Work Off-Farm, Hay Sales, or Renting-Out Land

The purpose of eliminating the alternative of selling hay was to force the feeding of the hay either to sheep or beef. With high crop yields, it was necessary to eliminate hay sales in order to accomplish this objective. On the same farm but with average crop yields, a plan not reported in detail here, the shift was from crop sales to the renting out of all but three acres of land. Therefore, as a safeguard against the discontinuance of farming, a restriction preventing renting out of land was also added to the small farm with high crop yields.

The restrictions imposed for this plan had permitted the examination of a farm organization using the land and labor resources for the production of forage crops then feeding them to non-dairy livestock. This resulted in 91 head of sheep which utilized all of the existing barn space. Compared to the Base Plan net revenue decreased from $\$ 10,019$ to $\$ 1,186$ (Table 14). Net revenue was derived from the sale of 1,024 bushels of grain and the wool and lambs from the sheep enterprise.

Only the Class II land was utilized for crop rotations. The crop rotation was the most intensive possible, two years of corn, wheat, and one year of clover-timothy hay. The rotational requirements used for the analysis were such that in order to produce the grain it was necessary to produce some hay crops. Only the minimum acres of hay were produced. Sheep were the most profitable non-dairy livestock. The size of the sheep flock was 
TABLE 13

Optimum Farm Plans, Small Farms, All Alternatives Considered Except No Dairy Cows Compared to the Base Plan

\begin{tabular}{|c|c|c|c|}
\hline 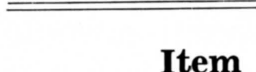 & Unit & $\begin{array}{l}\text { Base } \\
\text { Plan }\end{array}$ & $\underset{\text { Dairy Cows }}{\text { Plan Without }}$ \\
\hline
\end{tabular}

Livestock:

Dairy cows (1 lb.

grain/4.75 lbs. milk) Heal

Dairy replacements, raised Head Ewes

Head

Land:

Owned

Whole farm rented in

Acres

Acres

Class II only rented in

Acres

21

Crops:

Class II land

Corn, 2 yr.

Corn silage, 2 yr.

Oats

Wheat

Alfalfa hay, $5 \mathrm{yr}$.

Clover-timothy hay, 1 yr. Acres

Clover-timothy hay, 2 yr. Acres

Class III land

Corn, 1 yr.

Oats

Wheat

Alfalfa hay, 6 yr.

Class IV land

Wheat

Alfalfa hay, $7 \mathrm{yr}$.

Unimproved pasture

Class VI unimproved

pasture

Class VII idle

Crop sales:

Corn equivalent sales

Hay sales

Labor:

Total available labor

Operator and family

Part-time, year around hired

Work off-farm-winter

Seasonal bus driver

Labor unused

Spring

Summer

Fall

Capital:

Investment capital limit

Investment capital unused

Operating capital used

Net revenue:
Acres

Acres

Acres

Acres

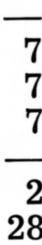

13

1

Acres

Acres

Acres

Acres

Acres

Acres

Acres

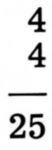

$\frac{4}{4}$

25

5

34

Acres

Acres

34

31

34

31

Bushels

Tons

9

115

1.951

277

Hours

4,182

3,642

3642

Hours

Hours

Hours

Lot

540

73

780

Hours

Hours

Hours

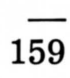

352

312

72

$\$$
$\$$
$\$$

16.600

16600

2,046

16,600

8,673

10,019 
limited by the capacity of the existing barn and it was not profitable to expand the barn to add more sheep. Since there was no other alternative use for the hay, additional hay production would have decreased net income. The corn silage production was just that amount required by the sheep. The hay and silage acreage determined the amount of land that could be used to produce crops for sale. The remaining land, except for Class VII, was used for pasture.

The only investment capital required was that needed to acquire the breeding flock and to expand the silo capacity by 23 tons. In spite of most of the land being used for pasture, some supplementary feeding was required during the late summer pasture period.

Enough unused labor remained by seasons to handle a fulltime 40-hour per week job off the farm. With agricultural activity so limited and net revenue so low, income sources other than farming would be necessary for the farmer and his family if they were to live without welfare assistance.

Differences in Income and Farm Organization with Beef Cattle in the Farm Plan

A farm plan with beef cattle as the only forage consuming livestock was considered. In order to arrive at this plan all of the restrictions of the previous plan were needed plus the removal of sheep from consideration. The net revenue of the plan with beef cattle was $\$ 791$ as compared to $\$ 10,019$ for the Base Plan (Table 14). The revenue came from the sale of 928 bushels of grain and seven yearling grass-fat steers.

Only the 21 acres of owned Class II land were farmed. The crop rotation, like that of the sheep farm, was of maximum intensity in order to capitalize upon the production of grain for sale. Beef cattle were kept to recover the hay costs, and enough ensilage was made to balance the feeding requirements of the beef. The Land Classes III, IV, and VI were used as pasture. A small amount of supplementary feeding of ensilage was required during the summer, but from a practical standpoint, the 14 acres of idle Class III land would be used to eliminate this feeding of supplementary silage.

All of the silo capacity was utilized but less than half of the barn space was used. Only the investment capital needed to acquire the brood cows was used.

There was more unused labor in each season with beef than 
TABLE 14

Optimum Farm Plans, Small Farms, All Alternatives Except No Dairy Cows, No Work Off-Farm, No Hay Sales or No Renting-Out of Land Compared to the Base Plan

\begin{tabular}{|c|c|c|c|c|}
\hline \multirow{2}{*}{ Item } & \multirow[b]{2}{*}{ Unit } & \multirow{2}{*}{$\begin{array}{l}\text { Base } \\
\text { Plan }\end{array}$} & \multicolumn{2}{|c|}{ Plans With } \\
\hline & & & Sheep & Beef \\
\hline \multicolumn{5}{|l|}{ Livestock: } \\
\hline \multicolumn{5}{|l|}{$\begin{array}{l}\text { Dairy cows (1 lb. } \\
\text { grain } / 4.75 \text { lbs. mil }\end{array}$} \\
\hline Dairy replacements, raised & Head & 8 & - & - \\
\hline Ewes & Head & - & 91 & - \\
\hline Beef cows & Head & - & - & 9 \\
\hline \multicolumn{5}{|l|}{ Land: } \\
\hline Owned & Acres & 113 & 113 & 113 \\
\hline Whole farm rented in & Acres & 54 & - & - \\
\hline Class II only rented in & Acres & 21 & 7 & 一 \\
\hline \multirow{2}{*}{\multicolumn{5}{|c|}{$\begin{array}{l}\text { Crops: } \\
\text { Class II land }\end{array}$}} \\
\hline & & & & \\
\hline $\begin{array}{l}\text { Corn, } 2 \text { yr. } \\
\text { Corn silage } 2 \text { vr }\end{array}$ & $\begin{array}{l}\text { Acres } \\
\text { Acres }\end{array}$ & $\overline{7}$ & $\begin{array}{r}10 \\
4\end{array}$ & $\begin{array}{l}8 \\
3\end{array}$ \\
\hline $\begin{array}{l}\text { Corn silage, } 2 \text { yr. } \\
\text { Oats }\end{array}$ & $\begin{array}{l}\text { Acres } \\
\text { Acres }\end{array}$ & 7 & $\begin{array}{l}4 \\
-\end{array}$ & -3 \\
\hline $\begin{array}{l}\text { Oats } \\
\text { Wheat }\end{array}$ & Acres & 7 & 7 & 5 \\
\hline $\begin{array}{l}\text { Wheat } \\
\text { Clover-timothy hay, } 1 \text { yr. }\end{array}$ & Acres & 2 & 7 & 5 \\
\hline Clover-timothy hay, 2 yr. & Acres & 28 & - & - \\
\hline \multicolumn{5}{|l|}{ Class III land } \\
\hline Corn, 1 yr. & Acres & 4 & - & - \\
\hline Oats & Acres & 4 & - & - \\
\hline Alfalfa hay, 6 yr. & Acres & 25 & - & - \\
\hline Improved pasture & Acres & - & 22 & 8 \\
\hline Idle & Acres & - & - & 14 \\
\hline \multicolumn{5}{|l|}{ Class IV land } \\
\hline Unimproved pasture & Acres & 39 & 26 & 26 \\
\hline \multicolumn{5}{|l|}{ Class VI unimproved } \\
\hline Class VII idle & Acres & 31 & 21 & 21 \\
\hline \multicolumn{5}{|l|}{ Crop sales: } \\
\hline Corn equivalent sales & Bushels & 9 & 1,024 & 928 \\
\hline Hay sales & Tons & 115 & - & - \\
\hline \multicolumn{5}{|l|}{ Labor: } \\
\hline Total available labor & Hours & 4,182 & 3642 & 3.642 \\
\hline Operator and family & Hours & 3642 & 3642 & 3,642 \\
\hline \multicolumn{5}{|l|}{ Part-time, year around } \\
\hline hired & Hours & 540 & - & - \\
\hline Work off-farm-winter & Hours & 73 & - & - \\
\hline \multicolumn{5}{|l|}{ Labor unused } \\
\hline Winter & Hours & - & 1.041 & 1.075 \\
\hline Spring & Hours & - & 854 & 1,003 \\
\hline Summer & Hours & 159 & 567 & 606 \\
\hline Fall & Hours & - & 486 & 529 \\
\hline \multicolumn{5}{|l|}{ Capital: } \\
\hline Investment capital limit & $\$$ & 16,600 & 16.600 & 16,600 \\
\hline Investment capital unused & $\$$ & 2,046 & 13,528 & 14,280 \\
\hline Operating capital used & $\$$ & 8,673 & 2,746 & 1,567 \\
\hline Net revenue: & $\$$ & 10,019 & 1,186 & 791 \\
\hline
\end{tabular}


with sheep. Therefore, a full-time job would become a possible means of using the surplus labor and increasing income.

\section{RESUME OF FARM PLANS}

The farm organizations of the large and small farms were very similar when the available alternatives and restrictions were comparable. Eight out of eleven farm organizations for both the large and small farms were based upon dairying as the main enterprise.

The large farm dairy organizations had either 45- or 30-cow dairy herds. The 45-cow herds required the hiring of a full-time, year-around man. With but one exception, the 30-cow dairy herds were operated with only the family labor supply. The one 30cow dairy herd that had a full-time hired man was the organization with milk priced at $\$ 4.00$ per hundredweight. The fulltime hired labor in the farm organization when milk was priced at $\$ 4.00$ was used to produce a larger acreage of field crops which was sold for cash. The 45-cow herds of the large plans were handicapped by a shortage of investment capital. The resource that limited the herd expansion of the 30-cow dairies was a shortage of family labor rather than investment capital, since approximately one-half of the available investment capital was unused.

The dairy herds of the small farm organizations did not show the division into distinct dairy herd sizes that the large farms did, but there was a notable feature relative to the herd size. The small farm organizations with over 23 dairy cows required approximately $\mathbf{5 0 0}$ hours of part-time, year-around hired labor. Those organizations with 23 or fewer dairy cows depended entirely upon the family labor supply. None of the small farm organizations could justify the employment of a full-time year-around hired man.

The ranking of net revenue from high to low among the eight organizations for the large and small farms as influenced by the various restrictions-milk price, average crop yields, no resource expansion, all-forage rations, and the required purchase of feed grain inputs-was not exactly the same order for the two farm sizes; but the effect of the different restrictions was basically the same (Table 15). High crop yields, a $\$ 5.00$ or $\$ 6.00$ milk price, and the feeding of heavy milk-grain ratios, whether the grain was produced or purchased, returned the largest net revenues (Rankings of $1,2,3,4$, and 5 , Table 15). The restrictions that returned the smallest net revenues were average field crop yields, all-forage 
TABLE 15

Rankings of Net Revenue for the Eight Dairy Farm Organizations Resulting from the Imposition of the Major Restrictions by Farm Size

\begin{tabular}{|c|c|c|c|c|}
\hline \multirow{3}{*}{ Restriction Employed } & \multicolumn{2}{|c|}{ Large Farm } & \multicolumn{2}{|c|}{ Small Farm } \\
\hline & \multicolumn{2}{|c|}{ Text Table } & \multicolumn{2}{|c|}{ Text Table } \\
\hline & Rank & No. & Rank & No. \\
\hline \multicolumn{5}{|l|}{ Milk Price per Hundredweight } \\
\hline$\$ 6.00$ & 1 & 4 & 1 & 10 \\
\hline$\$ 5.00$ & 2 & 3 & 2 & 9 \\
\hline$\$ 4.00$ & 8 & 4 & 7 & 10 \\
\hline Average Field Crop Yields & 6 & 3 & 6 & 9 \\
\hline \multicolumn{5}{|l|}{ No Land or Labor Expansion } \\
\hline Grain ration fed & 5 & 5 & 4 & 11 \\
\hline All-forage ration fed & 7 & 5 & 8 & 11 \\
\hline \multicolumn{5}{|l|}{ No Class I or II Land } \\
\hline Corn grain raised & 3 & 6 & 3 & 12 \\
\hline Corn grain purchased & 4 & 6 & 5 & 12 \\
\hline
\end{tabular}

rations, and the $\$ 4.00$ milk price. The Base Plan with $\$ 5.00$ milk, high crop yields, maximum resource expansion, and all alternatives available ranked second in net revenue for both farm sizes. Only the net revenue from the organization for $\$ 6.00$ milk exceeded the net revenue of the Base Plan, and over 96 per cent of the net revenue difference was explainable by the one dollar per hundredweight milk price differential.

The most profitable non-dairy farm organizations of the large and small farms were a cash crop, part-time organization, followed by an all sheep organization, and then by an all beef organization. The latter two organizations had low net revenues, and surplus quantities of family labor sufficient to permit one adult male laborer to hold a full-time, off-farm job.

\section{CONCLUSIONS}

Even though farmers in the Appalachian Plateau may be at a disadvantage in the production of milk as compared to other areas, the results of this study indicated that milk was produced at the least disadvantage among the available alternatives. Optimum farm organizations under a variety of conditions consistently resulted in a dairy farm organization. The dairy herd was always expanded to or nearly to the limits of the fall labor 
supply, the maximum land rental allowed, and the available investment capital. The dairy herd size was nearly double the herd size in the original sample. When no expansion of the land and labor resources was permitted, dairy farming was still the most profitable farm organization. When the cropland Classes were such that extensive use of the land was necessary, dairy farming was still the choice. If only average crop yields were possible, shortages of needed feed inputs were met through purchases, and dairying continued as the most profitable organization. Even if dairy cows were fed an all-forage ration dairying was still more profitable than beef or sheep enterprises.

The importance of feeding grain along with forages was evident in the dairy plans. Actually feeding the highest of the grain-milk ration considered was more profitable in every instance, when included in the analysis. Including an all-forage ration did not change the choice from dairy as the most profitable enterprise, but there was a substantial decrease in net revenue.

Some other significant results of the dairy plans were:

1. Through the adoption of recommended cropping practices crop yields for the area were profitably increased.

2. High crop yields produced excess hay which was sold.

3. The acreage of cropland in Classes II and III was usually adequate to produce the needed grain inputs. Most of the Class IV land was usually used as pasture. Class VI land was also used as pasture. Class VII land was rarely used.

4. There was usually a surplus of May and June pasture and a shortage of late summer pasture. Rather than improve the pastureland or use the Class VII pastureland, the late summer deficit was usually met by supplementary silage feeding. Surplus hay could have been used for this purpose in place of silage.

5. Pasture improvement was the exception rather than the rule.

6. All of the dairy herd replacements were raised. Dairy herd replacements were not purchased in any of the plans.

The cash crop, part-time organization offered the best alternative to dairy farming. Although this alternative was much more profitable than plans with sheep or beef enterprises, it did have rather specific assumptions which included: (a) a line of available farm machinery; (b) a market for the specific crops produced; and (c) a part-time job available in the seasons when there was excess labor. 
The study indicated that the sheep and beef enterprises were best if considered as a supplement to an off-farm job. Neither sheep or beef offered a revenue in themselves sufficient for a minimum standard of living, let alone cover returns to unpaid labor, management, and fixed costs.

The result of all farm organizations studied clearly showed that it was profitable to adopt recommended cropping practices for the area; expand the dairy herd to the maximum of land, labor, and capital resources; and feed grain to dairy cows equal to the largest grain-milk ratio included in the analysis.

\section{BIBLIOGRAPHY}

Barr, A. L. Sheep Production, Costs and Returns in West Virginia. Morgantown, West Virginia: West Virginia University, Agricultural Experiment Station, Bulletin 495, Revised 1966.

Barr, A. L., G. E. Toben, and C. C. Wilson, Jr. Resources, Production and Income in Eastern West Virginia Beef Cattle Farms. Morgantown, West Virginia: West Virginia University, Agricultural Experiment Station, Bulletin 546, May 1967.

Bird, Alan R. Poverty in Rural Areas of the United States. Washington: United States Department of Agriculture, Resource Development Economics Division, Agricultural Economics Report No. 63, November 1964.

Bureau of the Census. U. S. Census of Agriculture 1964. U. S. Department of Commerce, Vol. 1, Part 9, Table 6, for Pennsylvania, Maryland, and West Virginia.

Coltrane, R. I. and E. L. Baum. An Economic Survey of the Appalachian Region, with Special Reference to Agriculture. Washington: United States Department of Agriculture, E.R.S., Agricultural Economics Report 69, 1965.

Dailey, R. T., G. E. Frick, and R. H. McAlexander. Agricultural Planning Data for the Northeastern U. S., University Park, Pennsylvania: Department of Agricultural Economics and Rural Sociology, A. E. and R. S. 51, July 1965.

Farm Management Handbook. Ithaca: New York State College of Agriculture, Cornell University, Department of Agricultural Economics, A. E. Ext. 212, December 1962.

Heady, E. O., et al. Milk Production, Hay/Grain Substitution Rates an Economic Optima in Dairy Rations. Ames, Iowa: Agricultural Experiment Station, Iowa State College, Research Bulletin 444, October 1956.

Heady, E. O. and J. L. Dillon. Agricultural Production Functions. Ames, Iowa: Iowa State University Press, 1961. 
Heady, E. O., et al. Milk Production Functions in Relation to Feed Inputs, Cow Characteristics and Environmental Conditions. Ames, Iowa: Agricultural and Home Economics Experiment Station, Iowa State University of Science and Technology, Research Bulletin 529, July 1964.

Hoglund, C. R. "Economic Effects of High-Level Grain Feeding," Journal of Dairy Science. Champaign, Illinois: American Dairy Science Association, University of Illinois, Vol. 47, No. 10, October 1964, pp. 1128-1134.

Hutton, R. F. and James Becker. Economics of Dairy Cow Feeding. University Park, Pennsylvania: Agricultural Extension Service, The Pennsylvania State University, A. E. \& R. S. 28, March 1961.

Jensen, Einar, et al. Input-Output Relationship in Milk Production. Washington: U. S. Department of Agriculture, Technical Bulletin 815, U. S. Government Printing Office, 1952.

King, A. J. "The Master Sample of Agriculture," Journal of the American Statistical Association. March 1945.

Marshall, Alfred. Principles of Economics, 8th ed., London: Macmillan and Co., Ltd., 1959, pp. 264-285.

Pennsylvania Crop and Livestock Annual Summary and the Price Report. Harrisburg, Pennsylvania: Pennsylvania Crop Reporting Service, Department of Agriculture C.R.S. 44 and Monthly Report.

President's Appalachian Regional Commission. Appalachia. Report by the President's Appalachian Regional Commission, Washington: Government Printing Office, 1964.

Redman, J. C. and R. O. Olson. Economic Problems in Feeding Dairy Cows. Lexington, Kentucky: Kentucky Agricultural Experimental Station, University of Kentucky, Bulletin 648, 1956.

Redman, J. C., et al. Economic Analysis of Feeding Alternative Hay Qualities with Concentrates to Dairy Cows. Lexington, Kentucky: Kentucky Agricultural Experiment Station, University of Kentucky, Bulletin 694, February 1965.

Sharpe, George. Land Judging. Morgantown, West Virginia: Cooperative Extension Service, West Virginia University, Circular 386.

Sheehy, Seamus. "Selection of Representative Benchmark Farms in Synthetic Supply Estimation," Unpublished Ph.D. Dissertation, The Pennsylvania State University, University Park, Pennsylvania, 1964.

Smith, Edward J. Profitable Use of High Quality Forage on a Wisconsin Dairy Farm. Madison. Wisconsin: Department of Agricultural Economics, Ag. Econ. 18, July 1956. 
Soil and Water Conservation Needs Inventory, United States Department of Agriculture, State Soil Conservation Committees for Maryland, Pennsylvania and West Virginia, 1959.

United States Census of Agriculture. Washington: United States Department of Commerce, General Report, 1959. 
APPENDIX TABLE 1

Estimated Budget for One Acre of Corn Grain or Corn Silage, High Yields ${ }^{1}$

\begin{tabular}{|c|c|c|c|c|c|}
\hline \multirow[b]{3}{*}{ Input-Output Relationships } & \multicolumn{2}{|c|}{ Corn Grain } & \multicolumn{3}{|c|}{ Corn Ensilage } \\
\hline & \multicolumn{5}{|c|}{ Land Use Capability Class } \\
\hline & II & III & II & III & IV \\
\hline \multicolumn{6}{|l|}{ Production: ${ }^{2}$} \\
\hline Corn grain (bushels) & 100 & 80 & - & - & - \\
\hline Corn ensilage (tons) & - & - & 18.9 & 15.1 & 11.3 \\
\hline \multicolumn{6}{|l|}{ Expenses: } \\
\hline Seed & $\$ 3.75$ & $\$ 3.75$ & $\$ 3.60$ & $\$ 3.60$ & $\$ 3.60$ \\
\hline Fertilizer & 25.20 & 25.20 & 33.20 & 33.20 & 33.20 \\
\hline Lime & 3.80 & 3.80 & 3.80 & 3.80 & 3.80 \\
\hline Tractor & 8.48 & 8.83 & 10.72 & 10.64 & 11.67 \\
\hline Machinery $^{3}$ & 2.48 & 2.44 & 5.33 & 4.81 & 5.10 \\
\hline Total $^{4}$ & $\$ 43.71$ & $\$ 44.02$ & $\$ 56.65$ & $\$ 56.05$ & $\$ 57.37$ \\
\hline \multicolumn{6}{|l|}{ Man Labor: $:^{5}$} \\
\hline Spring (hours) & 6.1 & 6.7 & 6.6 & 7.3 & 8.2 \\
\hline Fall (hours) & 2.4 & 2.1 & 4.6 & 3.9 & 4.0 \\
\hline
\end{tabular}

${ }^{1}$ Estimates are based upon Dailey, R. T., Frick, G. E. and RicAlexander, R. H., Agricultural Planning Data for the Northeastern United States, Department of Agricultural Economics and Rural Sociology, A. E. \& R. S. 51 (University Park: The Pennsylvania State University, July 1965) Tables 6-14, pp. $22-31$, and adjusted for local conditions and yields.

${ }^{2}$ Production differences are due to differences in fertilization rates and the Land Capability Class effect, primarily erosion and droughtyness. Average yields of corn grain for Class II and III land are 65 and 55 bushels, respectively; average yields of corn ensilage for Class II, III, and IV land are 12.3, 10.4, and 7.5 tons, respectively.

3Corn grain expenses are estimated for large farms with single row corn pickers. Expenses for small farms, primarily due to custom hiring of corn picking, should be increased on Class II land by $\$ 5.05$, and on Class III land by $\$ 5.28$. Corn ensilage expenses for large farms assume owned field choppers. Expenses for small farms, primarily due to custom hiring of field chopping, should be increased on Class II land by $\$ 16.75$, Class III by $\$ 17.26$, and Class IV by $\$ 14.69$. The 1968 custom rate for corn picking reported by the Pennsylvania Crop Reporting Service, CRS-45, Mountain Section, was $\$ 7.20$ per acre. The 1968 custom rate for field chopping reported by the Pennsylvania Crop Reporting Service, CRS-45, Mountain Section, was $\$ 15.10$ per hour.

${ }^{4}$ Total expenses for average yields are lower due to less fertilizer, tractor, and machinery costs. Total expenses for corn grain are: Class II land $\$ 29.31$, and Class III land $\$ 30.26$. Total expenses for corn ensilage are: Class II land $\$ 35.59$, Class III $\$ 36.64$, and Class IV $\$ 38.46$. Total expenses of small farms should be further increased by the respective harves costs of footnote 3 .

${ }^{5}$ The spring season is defined as March 16 to June 30, and fall season as September 1 to October 31 . Labor requirements increase 10 per cent between Land Class II and Land Class III, and 25 per cent between Land Class II and Land Class IV. Fall labor requirements for average yields of corn grain decrease by .6 hour on Class II land, and .1 hour on Class III land. Spring labor requirements for average yields of corn ensilage decrease by .5 hour on Class II land, .4 hour on Class III land, and .1 hour on Class IV land. Fall labor required on small farms is less than on large farms since custom corn picking includes the labor of one man. Fall labor required on small farms Class II land average yield .9 hour, high yield 1.2 hours; and Class III land average yield 1.0 hours, high yield 1.1 hours. Fall labor required on small farms is less than on large farms since custom hiring of field chopping include two men, two wagons, two tractors, a chopper and blower. Fall labor required on small farm Class II land low yield, 1.1 hours, high yield 1.5 hours; Class III land low yield 1.2 hours, high yields 1.3 hours, and Class IV land low yield 1.3 hours, and 1.4 hours high yields. 
APPENDIX TABLE 2

Estimated Budget for One Acre of Oats or Wheat Grain

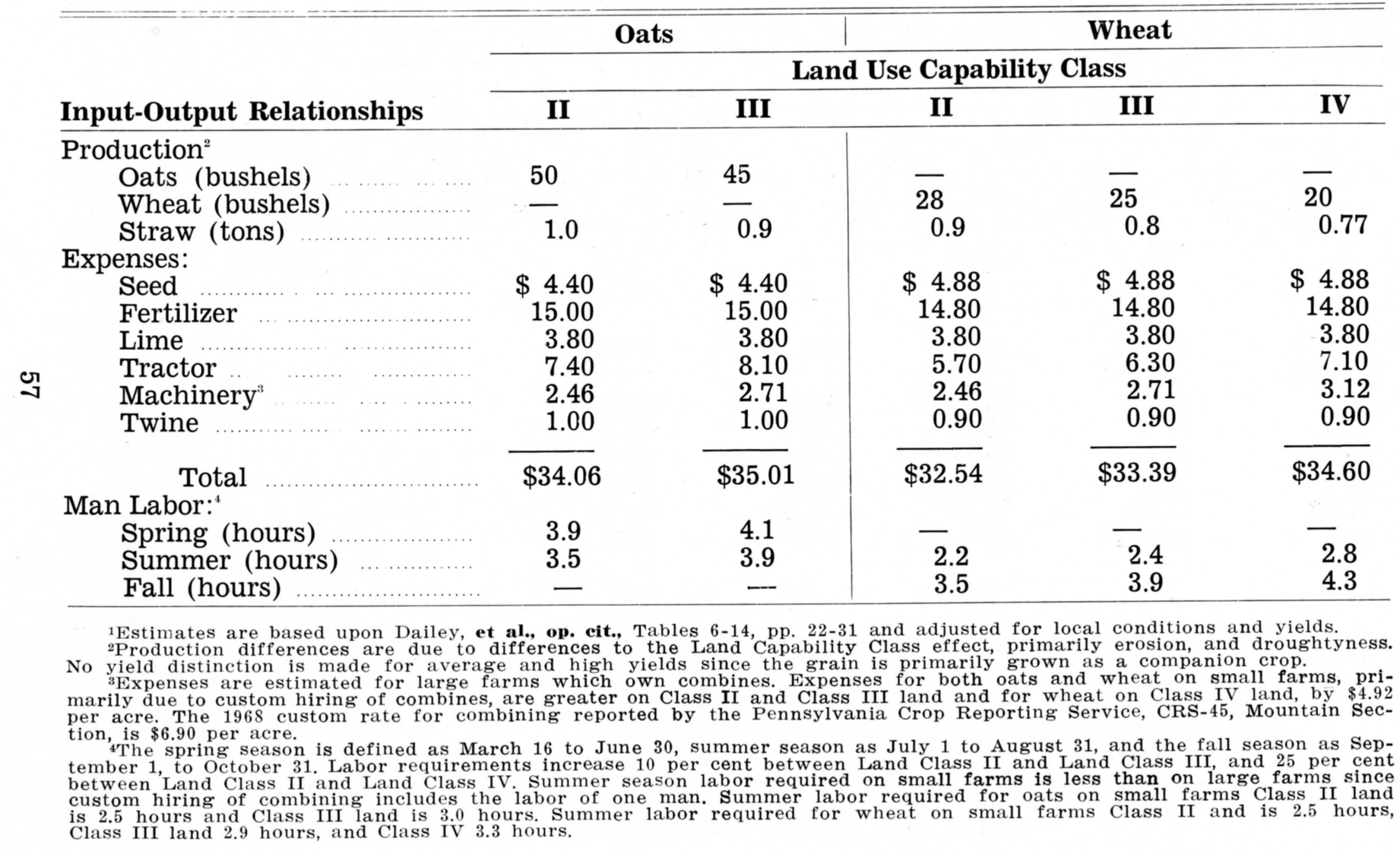


APPENDIX TABLE 3

Estimated Budget for One Acre of Clover-Timothy Hay, High Yields ${ }^{1}$

\begin{tabular}{|c|c|c|c|c|c|}
\hline \multirow[b]{3}{*}{ Input-Output Relationships } & \multicolumn{5}{|c|}{ Land Use Capability Class and Stand Life in Years } \\
\hline & \multicolumn{2}{|c|}{ II } & \multicolumn{2}{|c|}{ III } & \multirow{2}{*}{ IV } \\
\hline & One & Two & Two & Three & \\
\hline $\begin{array}{l}\text { Production }^{2} \\
\text { Clover-timothy hay (tons) }\end{array}$ & 3.75 & 3.0 & 3.0 & 2.4 & 1.8 \\
\hline 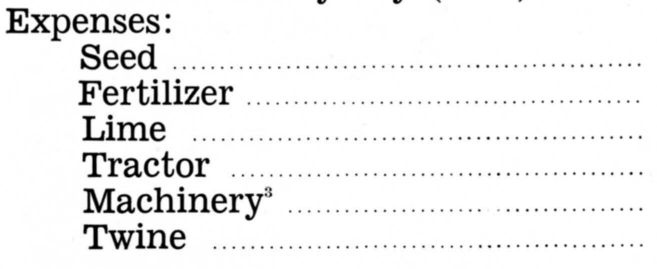 & $\begin{array}{r}\$ 7.80 \\
26.75 \\
7.60 \\
5.64 \\
2.75 \\
3.76\end{array}$ & $\begin{array}{r}\$ 3.90 \\
26.75 \\
7.60 \\
3.68 \\
1.94 \\
3.38\end{array}$ & $\begin{array}{r}\$ 3.90 \\
26.75 \\
7.60 \\
4.42 \\
2.04 \\
2.70\end{array}$ & $\begin{array}{r}\$ 2.60 \\
26.75 \\
7.60 \\
3.10 \\
1.44 \\
2.60\end{array}$ & $\begin{array}{r}\$ 1.95 \\
26.75 \\
7.60 \\
3.86 \\
1.77 \\
1.92\end{array}$ \\
\hline Total $^{4}$ & $\overline{\$ 54.30}$ & $\$ 47.25$ & $\$ 47.41$ & $\$ 44.09$ & $\$ 43.85$ \\
\hline $\begin{array}{l}\text { Man Labor: } \\
\text { Spring (hours) } \\
\text { Summer (hours) }\end{array}$ & $\begin{array}{l}6.2 \\
2.4\end{array}$ & $\begin{array}{l}3.7 \\
1.2 \\
\end{array}$ & $\begin{array}{l}5.5 \\
1.2 \\
\end{array}$ & $\begin{array}{l}5.4 \\
0.8\end{array}$ & $\begin{array}{l}5.1 \\
0.6\end{array}$ \\
\hline
\end{tabular}

1Estimates are based upon Dailey, et al., op. eit., Tables 6-14, pp. 22-31, and adjusted for local conditions and yields.

2Produtes a fin fertilization rates and the Land Capability Class effect, primarily erosion and drouction differences are due to difture of red clover and timothy. Clover harvest is the largest the year following the

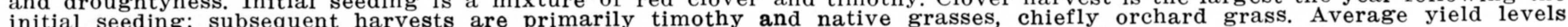
by Land Capability Classes. II, III and IV are 1.4 tons, 1.12 tons, and 84 tons, respectively.

larm arise from yield differences and machinery operating efficiency.

Total expenses for average yields are lower due to less fertilizer, tractor, machinery, and twine costs. Total expenses yields by Land Capability Classes and stand life are: Class II- $\$ 24.78$ and $\$ 20.04$; Class III- $\$ 20.02$ and $\$ 18.39$; and Class IV- $\$ 17.50$

${ }^{5}$ Man labor estimates are for the hay harvesting years only; spring labor includes annual fertilizing and hay harvesting labor; summer labor includes hay harvest only. Seeding labor was included in the small grain budgets. The spring season is defined as March 16 to June 30 , and summer season as July 1 to August 31 . Labor requirements increase 10 per cent between Land Class II and Land Class III, and 25 per cent between Land Class II and Land Class IV. Man labor for average yields III-3.2, 0.9 and $3.3,0.6$; and Class IV-3.2 and 0.5 , respectively. 
APPENDIX TABLE 4

Estimated Budget for One Acre of Alfalfa, First Cutting Harvested as Ensilage, Second and Third Cuttings Harvested as Hay, High Yields ${ }^{1}$

\begin{tabular}{|c|c|c|c|c|c|}
\hline \multirow[b]{3}{*}{ Input-Output Relationships } & \multicolumn{5}{|c|}{ Land Use Capability Class and Stand Life in Years } \\
\hline & \multicolumn{2}{|c|}{ II } & \multicolumn{2}{|c|}{ III } & \multirow{2}{*}{$\frac{\text { IV }}{\text { Seven }}$} \\
\hline & One & Five & Three & Six & \\
\hline \multicolumn{6}{|l|}{ Production: ${ }^{2}$} \\
\hline Alfalfa silage (tons) & 7.5 & 7.5 & 6.0 & 6.0 & 4.5 \\
\hline Alfalfa hay (tons) & 2.5 & 2.5 & 2.0 & 2.0 & \\
\hline \multicolumn{6}{|l|}{ Expenses: } \\
\hline Seed & $\$ 5.00$ & $\$ 2.00$ & $\$ 3.33$ & $\$ 1.67$ & $\$ 1.43$ \\
\hline Fertilizer & 20.28 & 20.28 & 20.28 & 20.28 & 20.28 \\
\hline Lime ....... & 7.60 & 7.60 & 7.60 & 7.60 & 7.60 \\
\hline Spray & 1.90 & 1.90 & 1.90 & 1.90 & 1.90 \\
\hline Tractor & 9.37 & 9.37 & 8.75 & 8.75 & 8.83 \\
\hline Machinery & 5.37 & 5.37 & 4.80 & 4.80 & 4.65 \\
\hline Twine & 3.00 & 3.00 & 2.50 & 2.50 & 2.00 \\
\hline Total $^{4}$ & $\overline{\$ 52.52}$ & $\$ 49.52$ & $\$ 49.16$ & $\$ 47.50$ & $\$ 46.69$ \\
\hline \multicolumn{6}{|l|}{ Man Labor: ${ }^{5}$} \\
\hline Spring (hours) & 5.2 & 5.2 & 5.7 & 5.7 & $\begin{array}{l}5.5 \\
23\end{array}$ \\
\hline Summer (hours) & 3.4 & 3.4 & 3.3 & 3.3 & 3.3 \\
\hline Fall (hours) & 3.1 & 3.1 & 3.0 & 3.0 & 3.0 \\
\hline
\end{tabular}

1Estimates are based upon Dailey, et al., op eit. Tables 6-14, pp. 21-34 and adjusted for local conditions and yields. and droughtyness. Annual fertilizing and liming rates are set to maintain alfalfa stands for several years without appreciable drops in production levels. Average yield levels for silage and hay by Land Capabs

-2.85 and 0.95 ; Class III- 2.62 and 0.88 ; and Class $14-2.25$ and 0.75 chopsers. Expenses for small farms primarily due to ${ }^{3}$ Alfalfa ensilage expenses for large farms assume owned field choppers. Expenses for sm $\$ 10.33$, and Class IV land by custom hing of $\$ 9.25$ per acre. The 1968 custom rate

4Total expenses for average yields are lower due to less fertilizing, tractor, and machinery costs. Average yield total "Total expenses for average yields are stand life are. Class II-\$27.41 and \$24.41: Class III- $\$ 26.34$ and $\$ 24.68$; and Class expenses by Land Capability Classes and stand IV- $\$ 24.97$, per acre. Total expenses of small $\$ 4$, arms and Land Class IV by $\$ 4.90$ per acre.

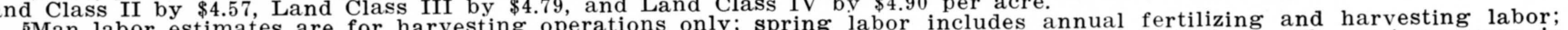
${ }^{5}$ Man labor estimates are for harvesting operations only, spring labor in the small grain budgets. The spring season is summer and fall labor is for hay harvest defined as March 16 to June 30 , sum ments nerease 10 per cent detween Land Class 1V. Fal labor II-2.7, 2.3, and 2.0; Class 11-2.8, 2.5, and 2.2, ano farms since custom field chopping includes 2 men, 2 wagons, and 2 smail farms with high yields are tractors. The spring labor reque per acre. 
APPENDIX TABLE 5

Estimated Budget for One Acre of Alfalfa All Cuttings Harvested as Hay, High Yields ${ }^{1}$

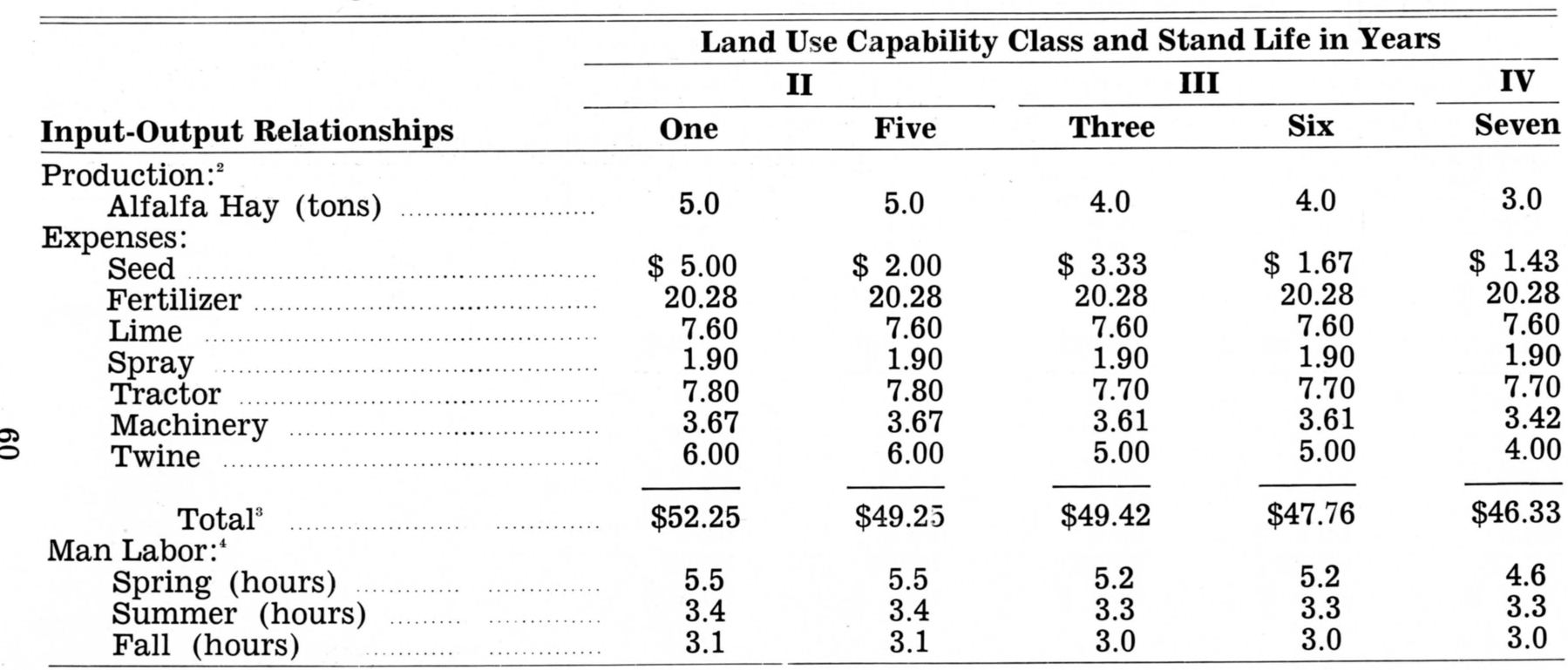

1Estimates are based upon Dailey, et al., op. eit., Tables 6-14, pp. 22-31, and adjusted for local conditions and yields.

2Production differences are due to differences in fertilization rates and the Land Capability Class effect, primarily erosion and droughtyness. Annual fertilizing and liming rates are set to maintain hay stands for several years without appreciable drops on production levels. Average yield levels of hay by Land Capability Classes are as follows: Class II-1.9, Class III- 1.75 , and Class IV- 1.5 tons per acre.

3Total expenses for average yields are lower due to less fertilizer, tractor, and machinery costs. Average yield total expenses beability Classes and stand life are: Class II- $\$ 27.35$ and $\$ 24.35$; Class III- $\$ 26.15$ and $\$ 24.49$; and Class IV

4Man labor estimates are for harvesting operations only; spring labor includes annual fertilizing and harvesting labor; summer and fall labor is for hay harvest only. Seeding labor was included in the small grain budgets. The spring season is defined as March 16 to June 30 , summer season July 1 to August 31, and fall season September 1 to October 31 . Labor requirements increase 10 per cent between Land Class II and Land Class III and 25 per cent between Land Class II and Land average yields by spring, summer, and fall seasons, respectively, Land Capability Classes are: Class II-2.9, 2.3, and 2.1; Class III-3.1, 2.5, and 2.2; and Class IV-3.1, 2.6, and 2.3 hours, respectively. 


\section{APPENDIX TABLE 6}

Estimated Budget for One Acre of Sudan Pasture on Class III Land, High Yields ${ }^{1}$

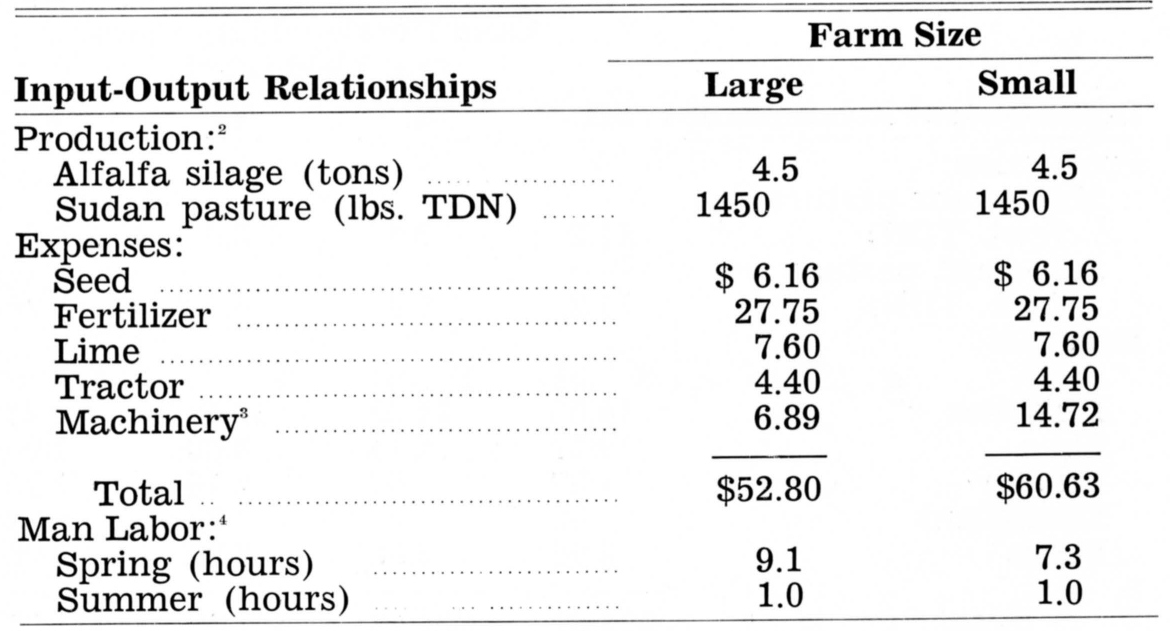

${ }^{1}$ Estimates are based upon Daily, et al., op eit., Tables 6-14, pp. 22-31 and adjusted for local conditions and yields.

2Sudan is seeded in an old alfalfa meadow after the alfalfa has been harvested as ensilage. The seeding is made in late May or early June. Sudan grass is rotationally pastured the balance of the growing season with as least 50 pounds of nitrogen applied after cattle have grazed of $\mathrm{it}$. No distinction is made in yield for sudan pasture between high and average vields as seeding is made annually and it is assumed that the sudan practices followed on both yield levels will be the same. The yield of alfalfa silage for average yield levels is 2.25 tons per acre.

${ }^{3}$ Expense differences between large and small farms arise from the alfalfa ensilage making operation. Large farms own field choppers and small farms custom hire the chopping operation. Custom chopping rate is 1968 rate reported by the Pennsylvania Crop Reporting Service CRS-45, Mountain Section, at $\$ 15.10$ per hour. Custom work includes 2 men, 2 wagons, 2 tractors, chopper, and blowers. ${ }_{4}^{4}$ The spring season is defined as March 16 to June 30 and summer as July 1 to August 31. Labor requirements increase 10 per cent between Class II and Class III land. Labor requirements for average yields of silage for the spring season are: large farm 6.2 hours and small farm 5.3 hours per acre. 


\section{APPENDIX TABLE $\boldsymbol{y}$}

Estimated Annual Budget for One Acre of Improved Pasture, High Yields ${ }^{1}$

\begin{tabular}{|c|c|c|c|c|}
\hline \multirow[b]{2}{*}{ Input-Output Relationships } & \multicolumn{4}{|c|}{$\begin{array}{c}\text { Land Use Capability Class } \\
\text { and Yield Level }\end{array}$} \\
\hline & III & IV & VI & VII \\
\hline \multicolumn{5}{|l|}{ Production: ${ }^{2}$} \\
\hline $\begin{array}{l}\text { May-June pasture } \\
\text { (cwt. TDN) } \\
\text { July-Sept. pasture }\end{array}$ & 11.2 & 9.6 & 8.0 & 4.5 \\
\hline (cwt. TDN) & 11.2 & 9.6 & 4.0 & 2.25 \\
\hline \multicolumn{5}{|l|}{ Expenses: ${ }^{3}$} \\
\hline Seed & $\$ .51$ & $\$ .51$ & $\$$ & $\$-$ \\
\hline Fertilizer & 14.53 & 14.53 & 12.45 & 6.23 \\
\hline Lime & 4.11 & 4.11 & 3.80 & 1.90 \\
\hline Tractor & 1.97 & 2.02 & 2.10 & 1.70 \\
\hline Equipment & .49 & .50 & .32 & .24 \\
\hline Fence & 2.96 & 2.96 & 2.96 & 2.96 \\
\hline Total & $\$ 24.57$ & $\$ 24.63$ & $\$ 21.63$ & $\$ 13.03$ \\
\hline \multicolumn{5}{|l|}{ Man Labor: ${ }^{4}$} \\
\hline Spring (hours) & 1.5 & 1.7 & 1.5 & 1.25 \\
\hline Summer (hours) & 1.1 & 1.3 & 1.5 & 1.25 \\
\hline
\end{tabular}

${ }^{1}$ Estimates are based upon Dailey, et al., op. eit., Tables 6-14, pp. 22-31, and adjusted for local conditions.

${ }^{2}$ Production differences are due to differences in fertilization rates and Land Capability Class effect, primarily erosion and droughtyness. The yield of pasture for average yield levels for May-June, and July-September by Land Capability Classes are: Class III-8.09 and 5.39; and Class IV-7.2 and 4.8 cwt. of TDN. There is only one yield level of improved pasture for Classes VI and VII land.

${ }^{3}$ Expenses on Land Classes III and IV include annual maintenance cost and one-tenth of the original seeding cost. Expenses for Land Class VI are annual costs only, no seeding was made. Expenses for Land Class VII are for only that portion of the land which can be covered with tractor and truck equipment.

${ }^{4}$ The spring season is defined as March 16 to June 30 , and summer season as July 1 to August 31. Labor requirements increase 10 per cent between Land Class II and Land Class III, and 25 per cent between Land Class II and Land Class IV. 
APPENDIX TABLE 8

Estimated Annual Budget for One Acre of Unimproved Pasture ${ }^{1}$

\section{Land Use Capability Class} and Yield Level

\begin{tabular}{|c|c|c|c|}
\hline Input-Output Relationships & IV & VI & VII \\
\hline \multicolumn{4}{|l|}{ Production: ${ }^{2}$} \\
\hline $\begin{array}{l}\text { May-June pasture } \\
\text { (cwt. TDN) }\end{array}$ & 6.82 & 6.45 & 2.85 \\
\hline July-September pasture & & & \\
\hline $\begin{array}{l}\text { (cwt. TDN) } \\
\text { (cwnes. }\end{array}$ & 3.47 & 2.15 & .95 \\
\hline $\begin{array}{l}\text { Expenses: } \\
\text { Tractor }\end{array}$ & $\$ 1.00$ & $\$ 1.00$ & $\$ .75$ \\
\hline Machinery & .15 & .15 & .10 \\
\hline Fence & 2.96 & 2.96 & 2.96 \\
\hline Total & $\$ 4.11$ & $\$ 4.11$ & $\$ 3.86$ \\
\hline Man Labor: ${ }^{4}$ & & & \\
\hline Summer (hours) & 1.0 & 1.0 & 1.0 \\
\hline
\end{tabular}

${ }^{1}$ Estimates are based upon Dailey, et al., op eit., Tables 6-14, pp. $22-31$ and adjusted for local conditions and yields.

2Production differences are due to natural feritlity, erosion, and droightyness. ${ }^{3}$ Expenses consist of mowing yearly and fence repair. Only a portion of Class VII land can be machine mowed and some hand mowing is required.

${ }^{4}$ Summer season is defined as July 1 to August 31. Differences in hours of tractor labor and man labor is explained by the portion of Class VI land that is hand mowed. 
APPENDIX TABLE 9

Annual Data for Dairy Cow Enterprise ${ }^{1}$

Receipts:

Milk $^{2}$

Cull cow

Bob Calf ${ }^{3}$

Total

Expenses:

Electricity $^{4}$

Veterinary $^{5}$

Breeding fee $^{5}$

Milk testing

Dairy supplies ${ }^{6}$

is Death loss

Machine operation ${ }^{4}$

Building repair ${ }^{6}$

Equipment repair ${ }^{6}$

Livestock insurance ${ }^{7}$

Total

Other Data:

Feed

\section{Item}

Milk production ${ }^{8}$

Total feed ingested ${ }^{10}$

Grain $^{11}$

Forage $^{11}$

Maximum pasture

May-June pasture

Culling rate $=25 \%$ of 1,200 lbs. @ $\$ 14.00$ cwt.

$\$ 42.00$

0.5 cwts.@\$20.00 cwt.

10.00

$\$ 52.00$

$188 \mathrm{KWH}$

4.13

4.92

6.00

6.00

16.00

2.0 per cent of average replacement value

5.74

3.34

1.0 per cent of new cost

6.30

2.0 per cent of new cost

2.30

0.5 per cent of average replacement value

1.44

$\$ 56.17^{8}$

Grain:milk Ratio

Unit

lbs.

lbs. TDN

lbs. TDN

lbs. TDN

lbs. TDN

lbs. TDN
1:11

11,000

7,348

1,030

6318

2,633

1,053
1:19

12,000

7,694

1.694

6000

2.500

1,000
1:4.95

13000

8,039

2,734

$5,305^{13}$

2.210

$\begin{array}{llll}2,675 & 2,649 & 2,633 & 2,500 \\ 1,060 & 1,070 & 1,053 & 1,000\end{array}$



Bedding
1.25 tons
@ \$20.00 ton
$\$ \quad 25.00$
Building cost (new) :
Overhead
$4,160.00$
Per cow
522.00
Building cost (expansion) ${ }^{6}$
416.00
Equipment cost (new) :
Overhead
$1,460.00$
Per cow
78.00
Equipment cost (expansion) ${ }^{6}$
78.00

${ }^{1}$ The cow was assumed to weigh 1,200 pounds and to yield 13,000 pounds of milk with 3.5 per cent fat when fed grain at

1:4.75 grain:milk ratio. $\$ 6.00$ per hundredweight, net of marketing charges.

${ }^{3}$ The calf crop was 93 per 100 cows, 58 of which were sold, 10 died between birth and freshening, leaving only 25 -heifers available as herd replacements.

${ }^{4}$ Based on information by Pritham S. Dhillon, "Inefficiency in Use of Resources in Relation to Low Income Problem on Dairy Farms in Southwestern Pennsylvania," (Unpublished doctoral dissertation, The Pennsylvania State University, University Park, Pennsylvania, 1964), pp. 125-127.

5Based on estimates of agricultural specialists of West Virginia University and W. L. Barr, "Investment and Data for Some Costs of Milk Production for Western Pennsylvania Dairy Farms," A. E. \& R. S. 27, November 1960, (University Park, Pennsylvania. The Pennsylvania State University), p. 6 and William $\mathrm{K}$. Waters, "Cost and Ret urns Guide for Livestock Enterprises in Southwestern Pennsylvania," Farm Management No. 34, May 9, 1966, (University Park, Pennsylvania: The Pennsylvania State University), p. 5.

${ }^{6}$ Based on information by Seamus J. Sheehy, "Selection of Representative Benchmark Farms in Synthetic Supply Estimation," (Unpublished doctoral dissertation, The Pennsylvania State University, University Park, Pennsylvania, 1964), pp. 201-203.

${ }^{7}$ Based on information on Pennsylvania Crops and Livestock Annual Summary 1965, C.R.
Pennsylvania Crop Reporting Service, The Pennsylvania Department of Agriculture), p. 16. sExpense total is for a dairy cow fed an all-forage ration. For dairy cows receiving a grain ration the cost of the following quantities of soybean oil meal should be added to each respective grain-milk ratio: $1: 30$, 20 lbs.; $1: 11$, 60 lbs.; $1: 7$, $90 \mathrm{lbs}$; and $1: 4.75,150 \mathrm{lbs}$. The costs should also include a charge for feed grinding for each grain-milk ratio as follows: $1: 30, \$ 1.61 ; 1: 11, \$ 4.59 ; 1: 7, \$ 8.25 ;$ and $1: 4.75, \$ 13.35$

•Based on John C. Redman and Russell O. Olson, Economic Problems in Feeding Dairy Cows, Kentucky Agricultura Experiment Station Bulletin 648, (Lexington: University of Kentucky), July, 1956, p. 17.

${ }_{10}$ Based on Nutrient Requirements of Dairy Cattle, National Academy of Sciences, Publication 1349, (Washington: National Research Council) 3rd Revised Edition, 1966, pp. 2-4.

${ }^{11 B a s e d}$ on Edward J. Smith, Profitable Use of High Quality Forage on a Wiseonsin Dairy Farm, Department of Agricultural Economics, Ag. Econ. 18, (Madison: University of Wisconsin, College of Agriculture), July 1956, p. 6 and pp. 35-40.

${ }^{12}$ Ration for 9,400 pounds of milk consists of 41.7 per cent of TDN requirement from good permanent pasture, rotational grazed containing 14.6 per cent TDN as described by Morrison's Feeds and Feeding, 22nd edition, p. 1028, Northern states and within the specified limitations of pasture maximums; $18.7 \mathrm{p}>\mathrm{r}$ cent of TDN requirement from corn silage, 18.3 per cen TDN; and 39.7 per cent of TDN renirement from good quality legume hay, 50 per cent TDN.

${ }^{13}$ Ration for 13,000 pounds of milk consists of 34 per cent o? TDN requirement from a grain ration and the remaining percentages of TDN from forages as described in footnote 12 a ove consisting of 27.5 per cent of TDN from pasture, 12.3 per cent corn silage, and 26.2 per cent leg 1 . e hay. 


\section{APPENDIX TABLE 10}

Annual Labor Data for Dairy Cow — Stanchion Barn

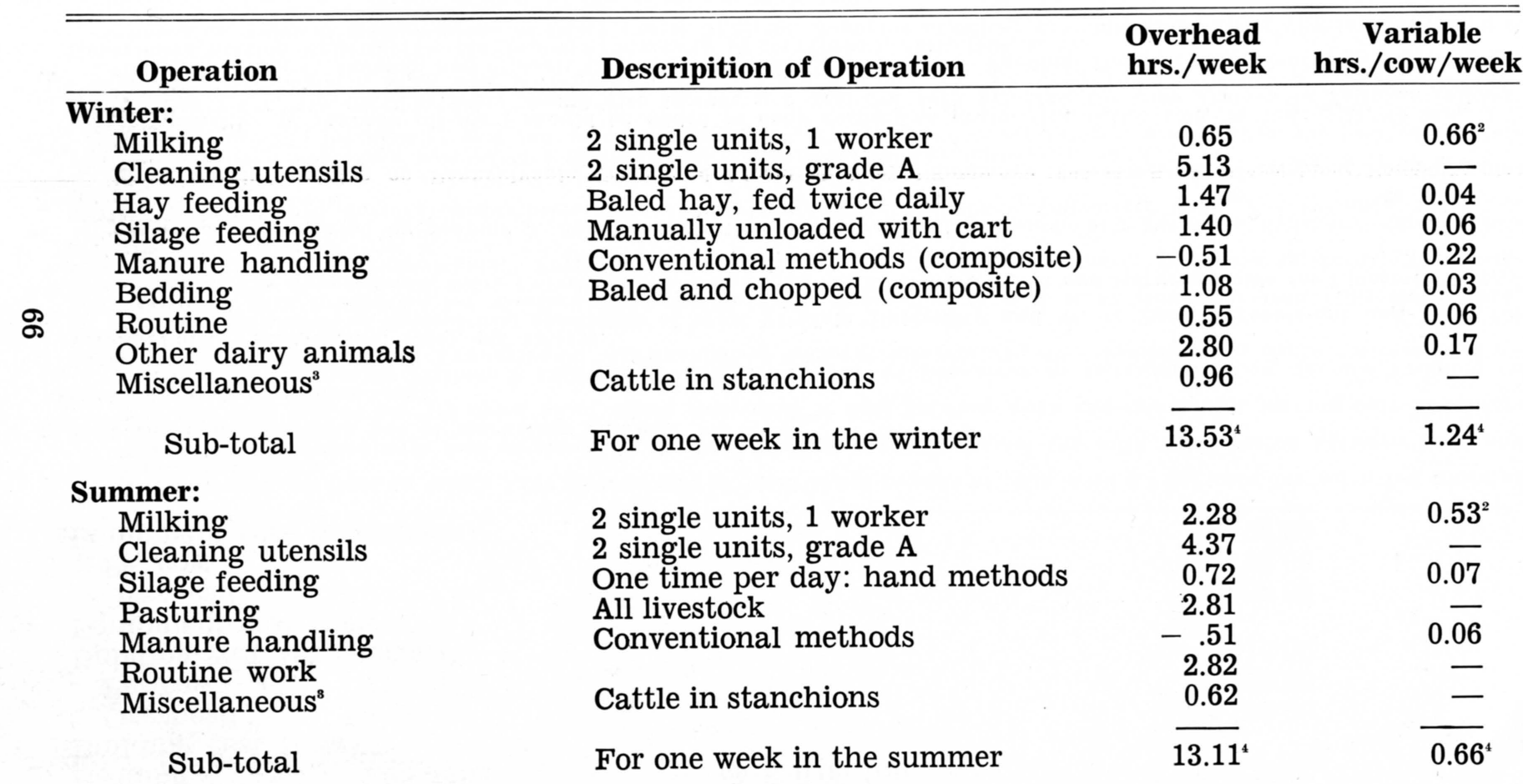




\section{Annual Labor Distribution ${ }^{5}$ Season \\ Winter, hours}

(November 1 - March 15)

Spring, hours

(March 16 - June 30)

Summer, hours

(July 1 - August 31)

Fall, hours

os (September 1 - October 31 )
Rate

19 weeks of winter

Open silo

9 weeks of winter

6 weeks of summer

\section{Overhead}

257

2

259

122

88

210

133

133

735
Variable 33.5

33.5

13.1

9.4

22.5

9 weeks of summer

9.9

9 weeks of summer Total

1Based on 1Based on Agricultural Planning Data for the Northeastern Unia State University). July, 1965, pp. 8-12.

Sociology, A. E. \& R. S. 51, (University Park: The Pennsylvania State University). July, 1965, pp. 8-12. Sheehy, "Selection of Assumes 81 per cent of the total cows in the herd mitimation," (Unpublished doctoral dissertation, The Pennsylvania Representative Benchmark Farms in Synthetic Supply Estimation,"

state University, University Park, Pennsylvania), 1964, pp. 204-205. per cow.

4Totals are adjusted to fit local technology and conditions.

4Totals are adjusted to fit local technology and conditions. herds of other sizes may be obtained by multiplying the variable factor by the appropriate herd size and then distributing the labor by seasons by multiplying both the variable labor and input labor by the appropriate weeks of the season. 
APPENDIX TABLE 11

Annual Data for a Dairy Cow Replacement

\section{Receipts: \\ Sterile heifer, $(0.12 \text { head })^{1}$ \\ Total \\ Expenses:

Milk replacer
Grain $^{3}$
Veterinary and medicine $^{4}$
Electricity $^{4}$
Machine operating costs $_{\text {Building repair }}$
Equipment repair $^{5}$
Breeding charge $^{4}$
Death loss $^{1}$
Livestock insurance $^{1}$

1.08 cwts. @ \$23.00

$\$ 24.84$

$\$ 24.84$

\section{Total}

Other Data:

Total feed ingested
Whole milk
Milk substitute
Grain
Forage
Maximum pasture
May-June pasture
Labor
Winter
Spring
Summer
Fall
Bedding
Building cost
Equipment cost
Equipm

0.5 cwt. - $\$ 20.00$ cwt. 7.50 cwt. @ \$4.00 cwt.

0.5 per cent of annual investment

lbs. TDN

lbs. TDN

lbs. TDN

lbs. TDN

lbs. TDN

lbs. TDN

lbs. TDN

hours

hours

hours

5.67

hours

6.10

0.5 tons@\$20.00 ton 3 and are based upon information supplied by Seamus J Sheehy "Selection of Representative Benchmark Farms in Synthetic Supply Estimation," (Unpublished doctoral dissertation, The Pennsylvania State University, University Park, Pennsylvania), 1964, pp. 201-203 and pp. 206-207.

${ }^{2}$ Based on J. B. Stone and Randolph Baker, Dairy Cattle Feeding Resource Data on Economies and Nutrition, Departments of Animal Husbandry and Agricultural Economics, A. E. Est. 383, (Ithaca: Cornell University), June 1965, p. 53.

${ }^{3}$ Grain is assumed to be a purchased commercial mix, no supplement or grinding is required.

"Based on information by Pritham S. Dhillon, "Inefficiency in Use of Resources in Relation to the Low Income Problem on Dairy Farms in Southwestern Pennsylvania," (Unpublished doctoral dissertation, The Pennsylvania State University, University Park, Pennsylvania), 1964, p. 128.

5 Agricultural Planning Data for the Northeastern United States, Department of Agricultural Economics and Rural Sociology, A. E. \& R. S. 51, (University Park: The Pennsylvania State University), July 1965 , p. 69.

'Nutrient requirements are based on Nutrient Requirements of Dairy Cattle, National Academy of Sciences, Publication 1349, (Washington: National Research Council), 3rd Revised Edition, 1966, pp. 2-4. 
APPENDIX TABLE 12

Annual Data for Beef Cow and Calf Enterprise ${ }^{1}$

Receipts: ${ }^{2}$

Calf

Cull cow

Total

Expenses: ${ }^{3}$

Minerals and salt ${ }^{4}$

Veterinary and medicine ${ }^{4}$

D Machine operating costs ${ }^{5}$

\& Building repair

Equipment repair

Livestock insurance ${ }^{5}$

Death loss $^{6}$

Marketing charges ${ }^{4}$

Total

Other Data:

Feed $^{7}$
3.33 cwt. @ $\$ 24.00$

1.6 cwt. @ $\$ 15.00$

0.30 cwt. @ $\$ 3.00$

0.90

2.00

0.65

1.0 per cent of new value

1.0 per cent of new value

0.5 per cent of average value $\$ 0.75$ per cwt.

0.50

0.16

1.25

1.25

1.20

$\$ 7.91$

(Continued on Next Page) 
APPENDIX TABLE 12 (Continued)

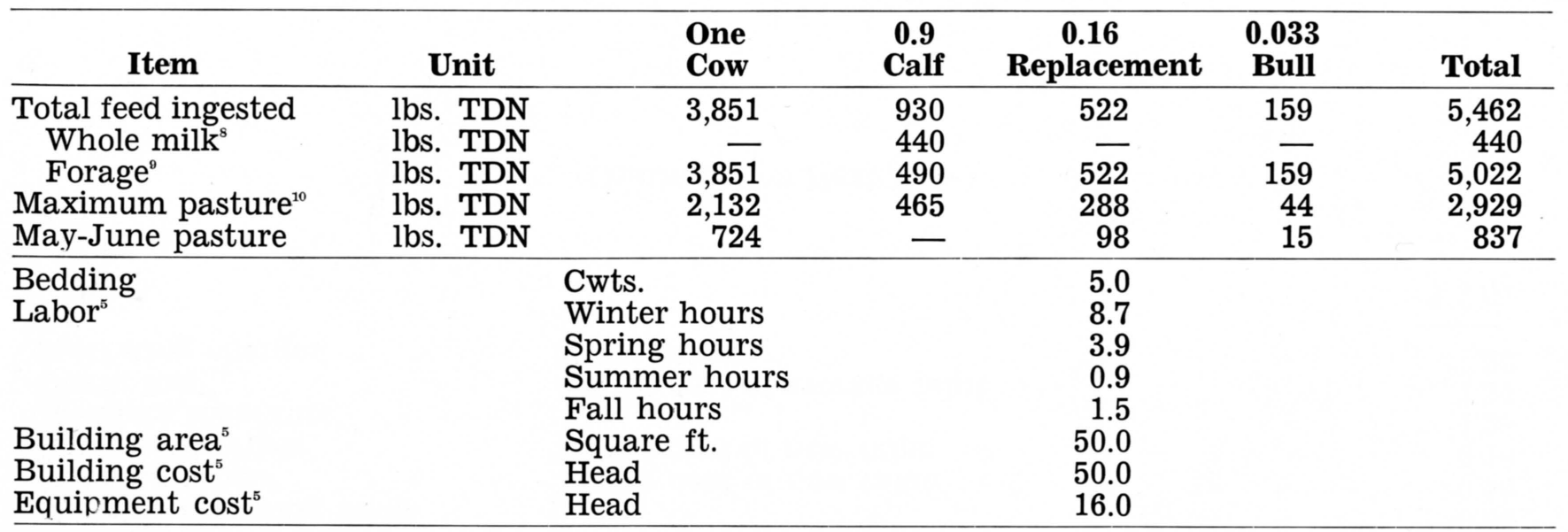

${ }^{1}$ Cows were asumed to weigh 1,000 lbs., calves born in January would weigh 450 lbs. by October 15 and grade good. ${ }^{2}$ Calf crop is estimated to be 90 per cent marketable calves, 16 per cent culling rate is assumed, thus 74 calves are sold per 100 cows based upon Alfred Barr, George Toben, and Charles Wilson, Resourees, Produetion and Ineome on Eastern west Virginia Beef Cattle Farms, West Virginia University, Agricultural Experiment Station Bulletin 546, (Morgantown: Department of Agricultural Economics), May 1967, p. 24

Costs for maintaining a bull are included in all items. One bull was assumed to serve 30 cows. Purchase and sale values of the bull are assumed equal.

Based on Alfred L. Barr, Beef Cattle Production, Costs and Returns for the Cow-Calf System in West Virginia, West Virginia University, Agricultural Experiment Station Bulletin 527, (Morgantown. Department of Agricultural Economics), June 1966 , Table 9.06 , p. 31 .

${ }^{5}$ Based on Agricultural Planning Data for the Northeastern United States, A. E. \& R. S. 51. The Pennsylvania State University, (University Park: Department of Agricultural Economics and Rural Sociology), July 1965 , p. 71.

${ }^{6}$ Based on Pritham Dhillon, "Inefficiency in Use of Resources in Relation to the Low Income on Dairy Farms in Southwestern Pennsylvania," (Unpublished doctoral dissertation, The Pennsylvania State University, University Park), 1964, p. 129

National Research Council), Tablee Animals.

${ }^{8}$ The cow is assumed to give at least 2,700 pounds of milk in 205 days.

${ }^{9}$ Maximum use is made of forage to feed all animal units, the cow, calf, replacements, and herd bull. Research reports, i.e., Alfred Barr, op. eit., Bulletin 527, Alfred Barr, et al., op. eit., Bulletin 546, and Frank Morrison's Feeds and Feeding, 22nd edition, p. 737 question the use of grain to creep feed calves. The normal grazing season is considered to be April 15 to November 15 during which period pasture will supply the TDN required for all livestock except the bull. For the bull, only onehalf the forage TDN could come from pasture.

${ }^{10}$ Maximum pasture intake is based on a seven months pasture season and calculated as seven-twelfths of total forage intake; maximum May-June pasture intake is two-sevenths of maximum pasture intake. 


\section{APPENDIX TABLE 13}

\section{Annual Data for Beef Spring Feeder Enterprise ${ }^{1}$}

\section{Receipts:}

Feeder

1.5 cwt. @ \$23.00

$\$ 34.50$

Expenses:

Minerals and salt ${ }^{2}$

Veterinary and medicine ${ }^{2}$

Building repair ${ }^{3}$

Machine operation $^{3}$

Equipment repair ${ }^{3}$

.15 cwt. @\$3.00

$\$ 0.45$

1.50

1.0 per cent of new value

0.30

1.0 per cent of new value

0.75

0.5 per cent of average value

0.10

Livestock insurance ${ }^{3}$

0.62

Death $\operatorname{loss}^{3}$

1.0 per cent of average value

0.50

Total

Other Data:

Feed $^{4}$

\section{Item}

Total feed ingested

Corn silage

Legume hay

Bedding $^{3}$

Labor $^{3}$

Fall

Winter

Building area ${ }^{3}$

Building cost ${ }^{3}$

Equipment cost ${ }^{3}$
Unit

lbs. TDN

lbs. TDN

lbs. TDN

Cwts.

Hours

Hours

Sq. ft.

Dollars

Dollars
Total Per Feeder

1,255

920

335

4

1.9

7.1

${ }^{1}$ Calves grading "good" and weighing 450 pounds were purchased or retained from the from the beef cow and calf enterprise as of winter to gain approximately three-fourths pound per day to and were sold as spring feeders but at a loss of a dollar per hundredweight.

2Based on estimates by specialists at the Agricultural Experiment Station, West Virginia University, Morgantown, West Virginia.

3Based on Seamus Sheehy, "Selection of Representative Benchmark Farms in Synthetic Supply Estimation," (Unpublished doctoral dissertation, The Pennsylvania State University, University Park, 1964), pp. 211-212.

yutrient Requirement of Beef Animais, Revised Edition, National Academy of Sciences, Publication 1137, (Washington: National Research Council), Table 1 , pp. 2-3. 


\section{APPENDIX TABLE 14}

\section{Annual Data for Grass Fattened Beef Enterprise}

\section{Receipts:}

Beef animal

2.18 cwt. @ \$22.00

$\$ 47.96$

\section{Expenses:}

Minerals and salt ${ }^{2}$

Veterinary and medicine ${ }^{2}$

.15 cwt. @ \$3.00

$\$ 0.45$

1.00

0.50

Spray materials ${ }^{3}$

0.05 per cent of average value 0.87

Livestock insurance ${ }^{4}$

Death loss ${ }^{4}$

1.0 per cent of purchase value

\section{Total}

\section{Other Data:}

Feed $^{5}$

Item

Total feed ingested

Forage

Hay equivalent

Maximum pasture

May-June pasture

Labor $^{3}$

Spring

Summer

Fall

\section{Unit}

lbs. TDN

lbs. TDN

lbs. TDN

lbs. TDN

lbs. TDN
Total Per Head

1,314

1,314

184

1,130

452

Hours $\quad 0.6$

Hours $\quad 0.6$

'Beef animals grading "good" and weighing 600 pounds were purchased or retained as spring feeders as of May 1 and placed on good permanent pasture for five months, where they gained approximately 1.4 pounds per day with a 218-pound gain. Still grading "good," they were sold the end of September as feeders. Selling price is assumed to be less than the average spring price.

${ }^{2}$ Based on estimates of specialists at the Agricultural Experiment Station at West Virginia University.

${ }^{3}$ Based on Ralph G. Kline, Economies of Adjustments for small Flue-Cured Tobaceo Farms Southside, Virginia, Virginia Polytechnic Institute, Technical Bulletin 174, (Blacksburg: Department of Agricultural Economics), June 1964, Appendix A, Table 19, p. 108.

${ }^{4}$ Based on Seamus Sheehy, "Selection of Representative Benchmark Farms in Synthetic Supply Estimation," (Unpublished doctoral dissertation, The Pennsylvania State University, University Park), 1964, pp. 211-212.

5Nutrient Requirements of Beef Animals, Revised Edition, National Academy of Sciences, Publication 1137, (Washington: National Research Council), Table 1, pp. 2-3. 
APPENDIX TABLE 15

Annual Data for Sheep Enterprise ${ }^{1}$

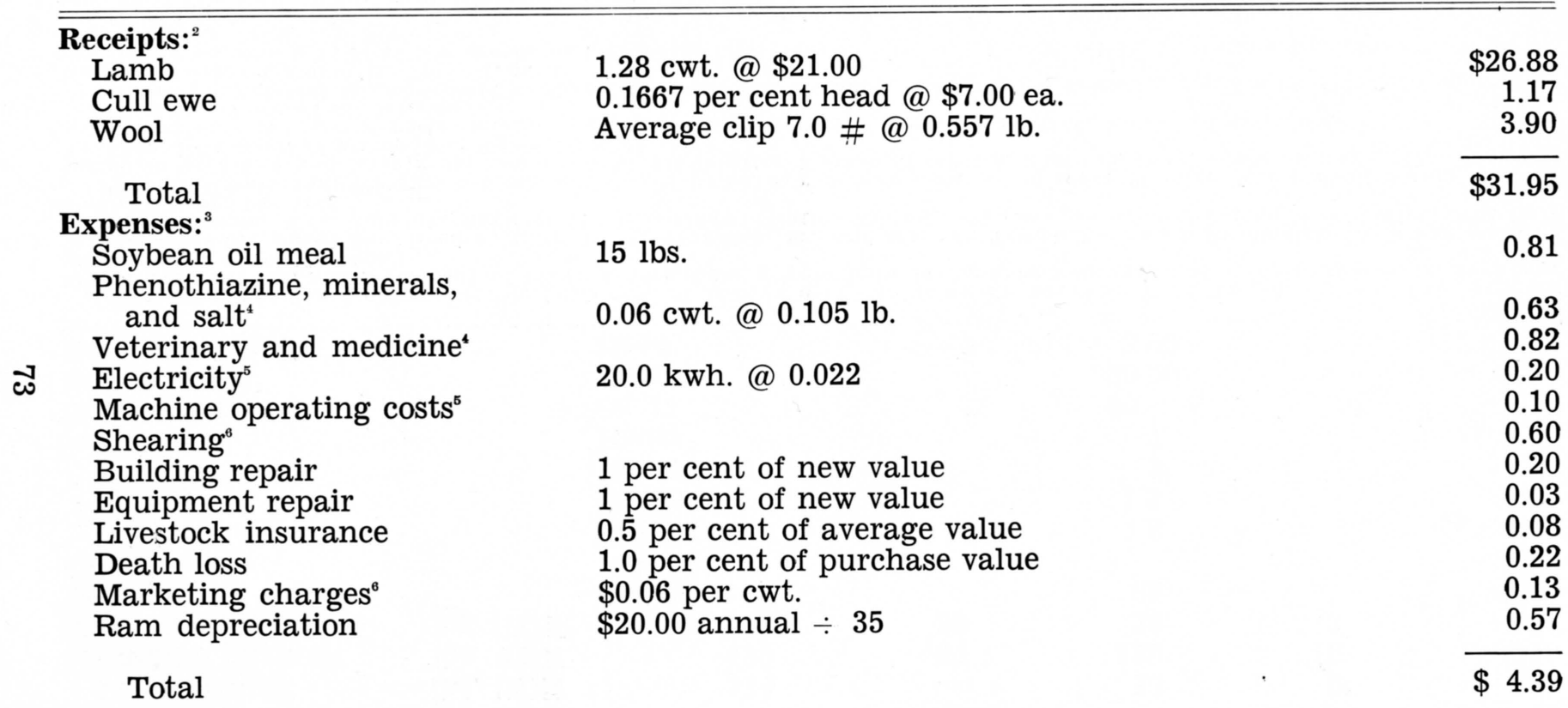

Other Data:

Feed $^{7}$

(Continued on Next Page) 
APPENDIX TABLE 15 (Continued)

\section{Item}

Total feed ingested

Milk $^{\mathrm{s}}$

Concentrates $^{6}$

Maximum pasture ${ }^{10}$

May-June pasture

Bedding $^{5}$

Labor $^{6}$

Winter

Spring

Summer

Fall

Building area ${ }^{11}$

A Building cost

Eauipment cost ${ }^{4}$
One

Ewe

lbs. TDN

lbs. TDN

lbs. TDN

lbs. TDN

lbs. TDN

861

$\overline{114}$

499

112

Cwt.

Hours

Hours

Hours

Hours

Sq. ft.

Head

Head
$1.2 \%$

137

40

67

35

0.18
Replacement
244
$\overline{13}$
129
28
.85

1.8

1.5

.3

.7

20.00

3.00

${ }^{1}$ Estimates are based on marketable lamb crop of 153 per cent, weighing an average of 95 pounds, 89 per cent grading blue, 9 per cent red, and 2 per cent of lower grades. Lambs were born in January-February and sold in June-July. Ewe size was assumed to be 150 pounds.

${ }^{2}$ Receipts are based on Alfred L. Barr, B. W. Wamsley, Jr., and Mary C. Templeton, Sheep Produetion Costs and Returns in West Virginia, West Virginia Agricultural Experiment Station Bulletin 495 (Morgantown: Department of Agricultural Economics), November 1966 .

${ }^{3}$ Costs of maintaining a ram are included in all items. A ram was assumed to serve 35 ewes. The cost of a ram was assumed to be $\$ 75.00$ and have a salvage value of $\$ 15.00$ after 3 years of service. Based on Barr, et al., op eit., p. 17 .

${ }^{4}$ Based on Barr, et al., op. eit., Table 11, p. 18.

${ }^{5}$ Based on estimates of specialists at the Agricultural Experiment Station at West Virginia University.

${ }^{6}$ Based on Barr, et al., loc. eit. National Research Council), Table 1, p. 2.

${ }^{8}$ Based on Frank B. Morrison, Feeds and Feeding, 22nd Edition, (Ithaca: The Morrison Publishing Company), 1956, p. 800 and Appendix Table 1, p. 1056.

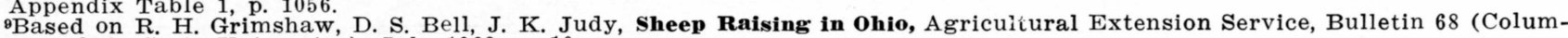
bus: The Ohio State University), July 1963 , p. 10.

${ }^{10}$ The grazing season was considered to be from May 1 to December 1. All forage TDN during this period could come from pasture. Pasture would supply seven-twelfths of total forage intake; maximum May-June pasture intake is two-sevenths

of the maximum pasture intake. p. 210, and Specialists at the Agricultural Experiment Station, West Virginia University. 
APPENDIX TABLE 16

List of Alternatives Included for the Linear Programming Model by Land Capability Classes for Crops, Crop Production Yield per Acre for High and Average Yield Farms, Livestock Production Yield per Head, and Miscellaneous Activities

\begin{tabular}{|c|c|c|c|c|c|}
\hline \multirow{2}{*}{\multicolumn{2}{|c|}{ Activity }} & \multicolumn{4}{|c|}{ Yield Level } \\
\hline & & \multicolumn{2}{|c|}{ High } & \multicolumn{2}{|c|}{ Average } \\
\hline $\begin{array}{l}\text { Crops: } \\
\text { Land capability }\end{array}$ & Class I-II & & & & \\
\hline $\begin{array}{l}\text { Land capabillty } \\
\text { Corn grain }\end{array}$ & 1 st yr. & 100 & & & \\
\hline Corn silage & 1 st yr. & 18.9 & tons & 12.3 & $\begin{array}{l}\text { bu. } \\
\text { tons }\end{array}$ \\
\hline Corn grain & 2nd yr. & 100 & bu. & 65 & bu. \\
\hline Corn silage & 2nd yr. & 18.9 & tons & 12.3 & tons \\
\hline Wheat grain & & & bu. & 28 & bu. \\
\hline Oats grain & & & bu. & 50 & bu. \\
\hline Red clo & $1 \mathrm{yr}$. & 3.75 & tons & 1.4 & tons \\
\hline Clover-timothy hay & $2 \mathrm{yr}$. & & & & \\
\hline Clover & & 3.75 & tons & $\begin{array}{l}1.4 \\
1.4\end{array}$ & tons \\
\hline Timothy & & 3.0 & tons & & \\
\hline Alfalfa silage & $2 \& 5 \mathrm{yr}$. & & & & \\
\hline Silage & & 7.5 & tons & 2.85 & tons \\
\hline Hay & yearly & 2.5 & tons & & \\
\hline Alfalfa hay & $2 \& 5$ yr. & & & & \\
\hline Hay & $\begin{array}{l}\text { yearly } \\
\text { Class }\end{array}$ & 5.0 & tons & 1.9 & tons \\
\hline $\begin{array}{l}\text { Land capability } \\
\text { Corn grain }\end{array}$ & Class III & 80 & bu. & 55 & \\
\hline $\begin{array}{l}\text { Corn grain } \\
\text { Corn silage }\end{array}$ & & 15.1 & tons & 10.4 & tons \\
\hline Wheat grain & & 25 & bu. & 25 & bu. \\
\hline Oats gr & & 45 & bu. & 45 & bu. \\
\hline Clover-timothy hay & $2 \mathrm{yr}$. & & & & \\
\hline Clover & & 3.0 & tons & 1.12 & tons \\
\hline Timothy & & 2.4 & tons & 1.12 & tor \\
\hline Clover-timothy hay & $3 \mathrm{yr}$. & & & & \\
\hline Clover. & & 3.0 & tons & 1.12 & tons \\
\hline Alfalfa silage & 3 \& 6 yr. & & & & \\
\hline Silage & yearl & 6.0 & tons & 2.62 & ton \\
\hline $\mathrm{Ha}$ & yearly & 2.0 & tons & .875 & 5 ton \\
\hline Alfalfa hay & $3 \& 6$ yr. & & & & \\
\hline Hay & yearly & 4.0 & tons & 1.75 & tons \\
\hline Alfalfa sudan & $1 \mathrm{yr}$. & & & & \\
\hline $\begin{array}{l}\text { Alfalfa silage } \\
\text { Sudan pasture }\end{array}$ & & $\begin{array}{c}4.5 \\
1450 \text { lbs. }\end{array}$ & $\begin{array}{l}\text { tons } \\
\text { TDN }\end{array}$ & $\begin{array}{r}2.25 \\
1450 \mathrm{lbs} .\end{array}$ & $\begin{array}{r}\text { tons } \\
\text { TDN }\end{array}$ \\
\hline Land capability & Class IV & & & & \\
\hline Corn silage & & 11.3 & tons & 7.5 & tons \\
\hline Wheat grain & & 20 & bu. & 20 & bu. \\
\hline Clover-timothy hay & $4 \mathrm{yr}$. & & & & \\
\hline $\begin{array}{c}\text { Timothy } \\
\text { Alfalfa silage }\end{array}$ & & 1.8 & tons & .84 & tor \\
\hline $\begin{array}{l}\text { Alfalfa silage } \\
\text { Silage }\end{array}$ & $7 \mathrm{yr}$. & & & & \\
\hline $\begin{array}{l}\text { Silage } \\
\text { Hay }\end{array}$ & $\begin{array}{l}\text { yearly } \\
\text { yearly }\end{array}$ & $\begin{array}{l}4.5 \\
1.5\end{array}$ & $\begin{array}{l}\text { tons } \\
\text { tons }\end{array}$ & $\begin{array}{r}2.45 \\
.75\end{array}$ & 01 \\
\hline Alfalfa hay & $7 \mathrm{yr}$. & & & & \\
\hline Hay & & 3.0 & tons & 1.5 & \\
\hline
\end{tabular}


APPENDIX TABLE 16 (Continued)

\begin{tabular}{|c|c|c|c|}
\hline \multirow{2}{*}{\multicolumn{2}{|c|}{ Activity }} & \multicolumn{2}{|c|}{ Yield Level } \\
\hline & & High & Average \\
\hline \multicolumn{4}{|c|}{$\begin{array}{l}\text { Pasture: } \\
\text { (Rotationally grazed) }\end{array}$} \\
\hline Land capability & Class III & & \\
\hline Improved & & $2,240 \mathrm{lbs} . \mathrm{TDN}$ & 1,348 lbs. TDN \\
\hline Land capability & Class IV & & \\
\hline $\begin{array}{l}\text { Improved } \\
\text { Unimproved }\end{array}$ & & 1,920 lbs. TDN & 1,200 lbs. TDN \\
\hline $\begin{array}{l}\text { Unimproved } \\
\text { Land capability }\end{array}$ & Class VI & lbs. TDN & 1,029 IDS. TDN \\
\hline Improved & & $1,200 \mathrm{lbs} . \mathrm{TDN}$ & $1,200 \mathrm{lbs} . \mathrm{TDN}$ \\
\hline Unimproved & & $860 \mathrm{lbs} . \mathrm{TDN}$ & $860 \mathrm{lbs} . \mathrm{TDN}$ \\
\hline $\begin{array}{l}\text { Land capability } \\
\text { Improved }\end{array}$ & Class VII & & \\
\hline Unimproved & & 380 lbs. TDN & $380 \mathrm{lbs}$. TDN \\
\hline
\end{tabular}

Livestock:

\section{Yield Per Head}

Dairy cows

$100 \%$ forage milk

$1: 30$ grain-milk

$1: 11 \quad$ grain-milk

1:7 grain-milk

Beef

1:4.75 grain-milk

Cow-calf calf wt./cow

Spring feeder wt./cow

$9,400 \mathrm{lbs}$.

10,000 lbs.

11,000 lbs.

$12.000 \mathrm{lbs}$.

$13,000 \mathrm{lbs}$.

Sheep

Ewe-lamb lamb wt./ewe

333 lbs.

600 lbs.

818 lbs.

$128 \mathrm{lbs}$.

\begin{tabular}{lc}
\hline Activity & Expressed Units \\
\hline Miscellaneous: & \\
Buying activities & 1 bushel \\
Corn grain & 1 ton \\
Hay & 1 ton \\
Bedding & 1 dollar \\
Operating capital & 1 hour \\
Labor & 1 acre \\
Land rent-in & 1 head \\
Remodel barn & 1 head \\
Expand dairy barn & 100 sq. ft. \\
Expand livestock barn & 1 ton \\
Expand silo & 1 head \\
Hay dairy replacement & 1 bushel \\
Selling activities & 1 ton \\
Corn grain & 1 hour \\
Hay & 1 man \\
Winter labor & 1 acre \\
Bus driver & 1 hundredweight \\
Land rent-out & 1 hundredweight \\
Milk & 1 hundredweight \\
Beef & 1 lot \\
Lamb & 1 Oar activities \\
Dairy fixed labor &
\end{tabular}


[Blank Page in Original Bulletin] 
[Blank Page in Original Bulletin] 